\title{
Supporting Tribunal Users: Access to pre-hearing information, advice and support in Northern Ireland
}

McKeever, G. (2011). Supporting Tribunal Users: Access to pre-hearing information, advice and support in Northern Ireland. Law Centre (NI).

http://www.lawcentreni.org/Publications/SupportingTribunalUsers2011ELECTRONICVERSION.pdf

Link to publication record in Ulster University Research Portal

Publication Status:

Published (in print/issue): 01/11/2011

\section{Document Version}

Publisher's PDF, also known as Version of record

\section{General rights}

Copyright for the publications made accessible via Ulster University's Research Portal is retained by the author(s) and / or other copyright owners and it is a condition of accessing these publications that users recognise and abide by the legal requirements associated with these rights.

\section{Take down policy}

The Research Portal is Ulster University's institutional repository that provides access to Ulster's research outputs. Every effort has been made to ensure that content in the Research Portal does not infringe any person's rights, or applicable UK laws. If you discover content in the Research Portal that you believe breaches copyright or violates any law, please contact pure-support@ulster.ac.uk. 


\section{Supporting Tribunal Users}

Access to pre-hearing information, advice and support in Northern Ireland

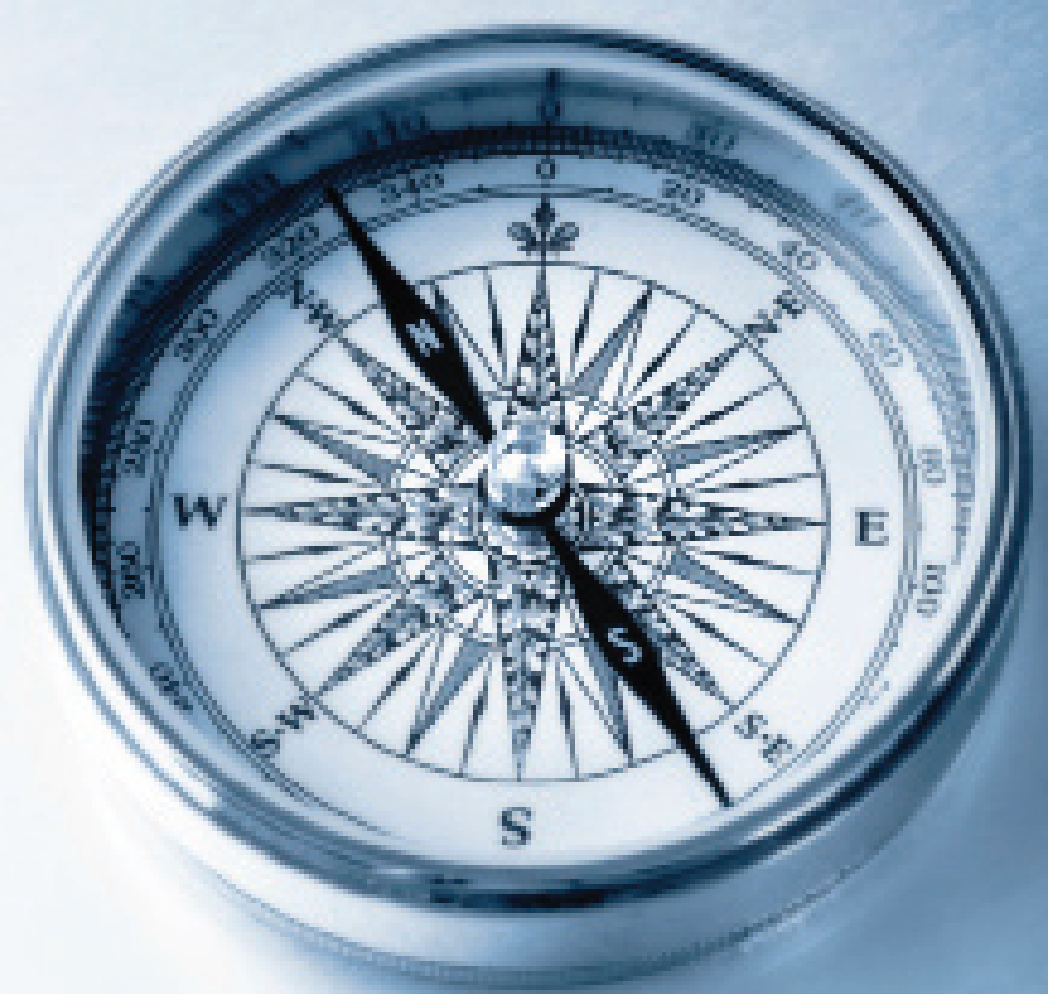

Gráinne McKeever | School of Law, University Ulster

Published by Law Centre (NI) 
Supporting Tribunal Users

Access to pre-hearing information, advice and support in Northern Ireland Gráinne McKeever

Published by Law Centre (NI) with support from Nuffield Foundation November 2011

Electronic version

Cover pictures: Sarah Lee

ISBN: 978-1-872299-13-6

(CLaw Centre (NI), Gráinne McKeever 2011 


\section{Supporting Tribunal Users}

Access to pre-hearing information, advice and support in Northern Ireland

Gráinne McKeever 


\section{CONTENTS}

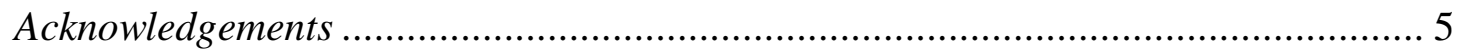

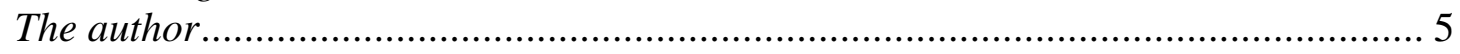

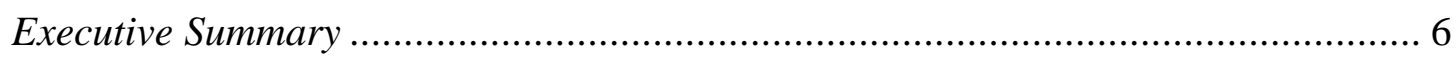

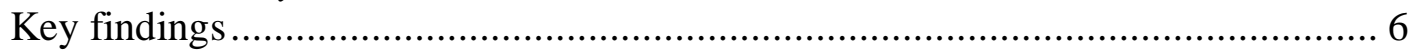

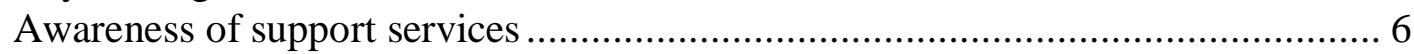

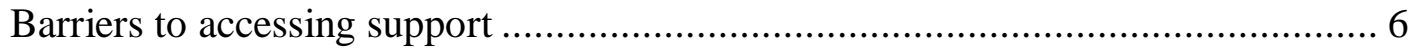

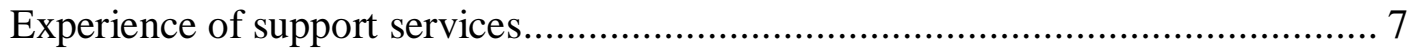

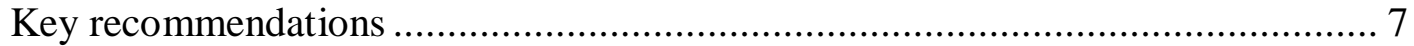

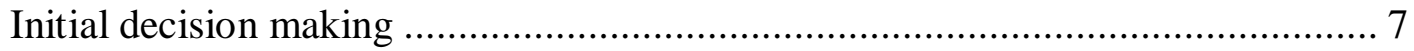

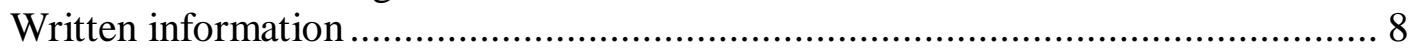

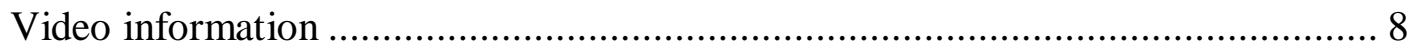

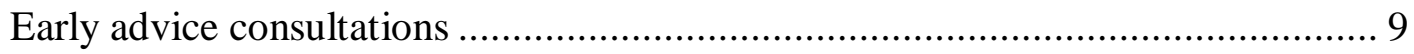

Facilitating referrals for users ..................................................................... 9

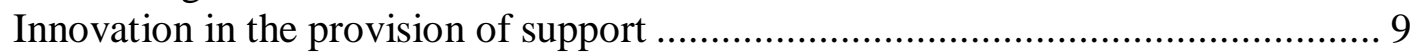

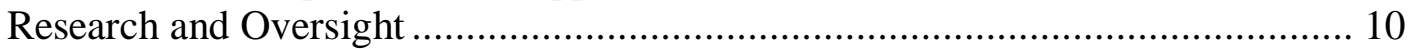

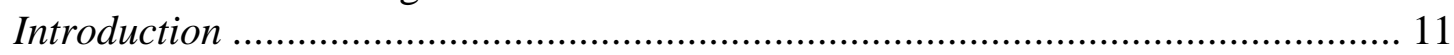

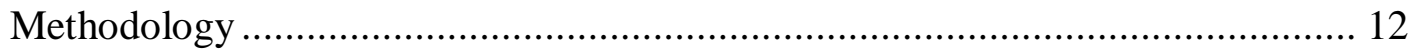

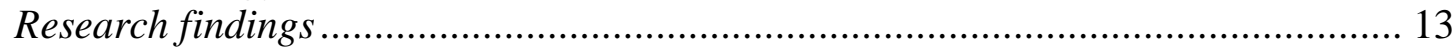

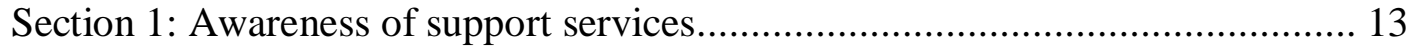

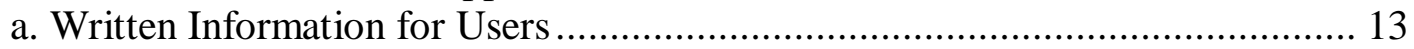

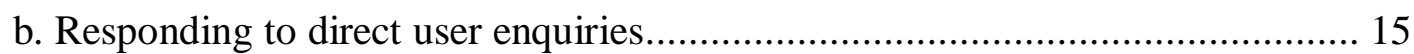

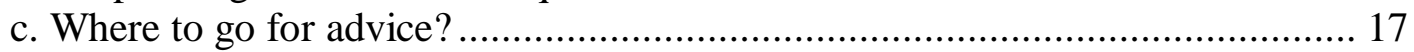

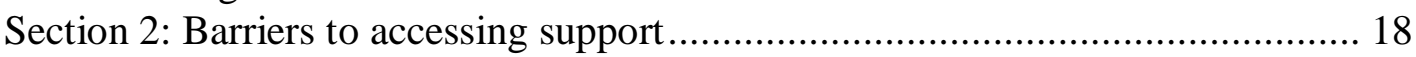

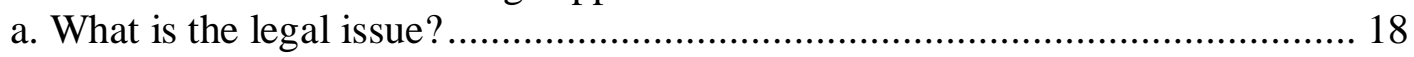

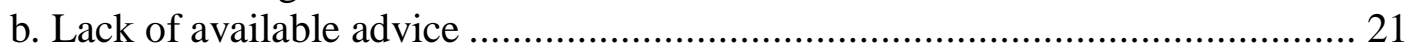

c. Not understanding written information and advice ....................................... 23

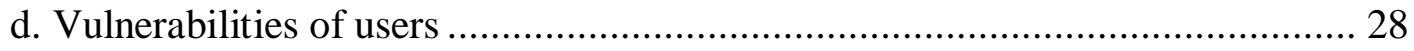

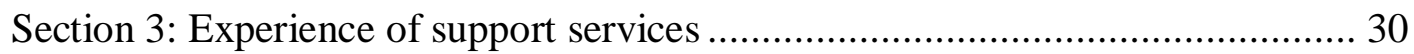

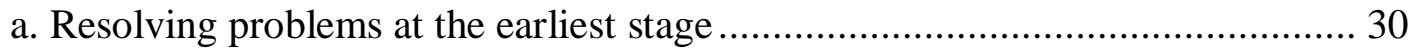

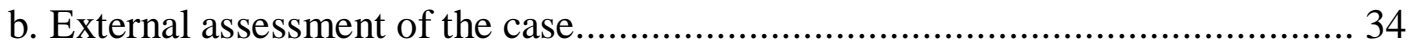

c. Awareness of tribunal rules and procedures ................................................... 34

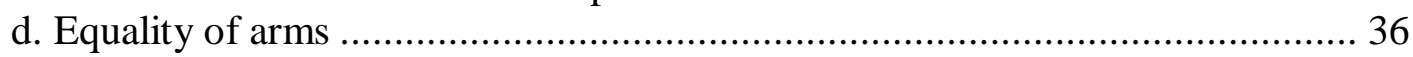

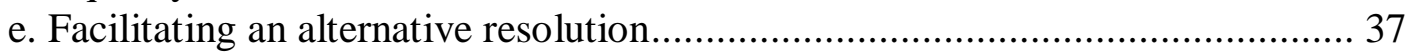

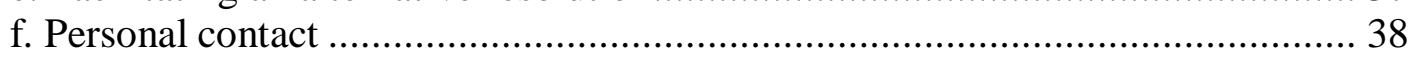

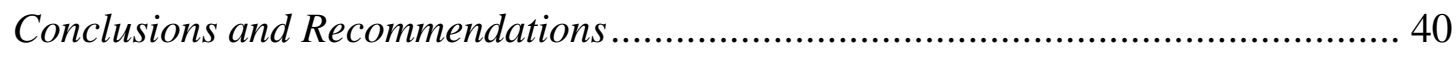

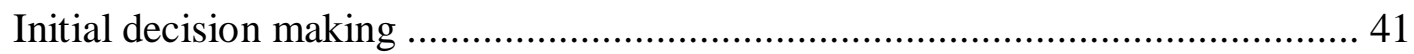

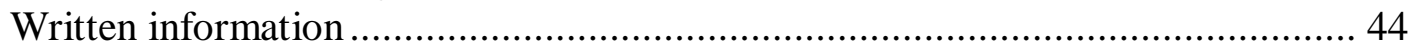

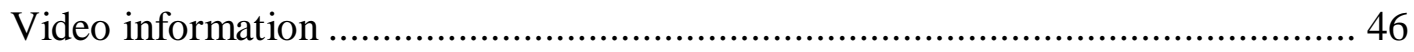

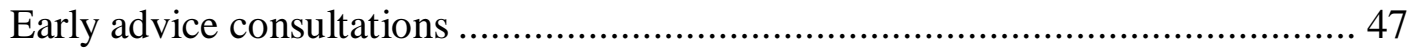

Facilitating referrals for users ................................................................ 49

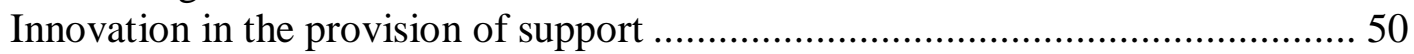

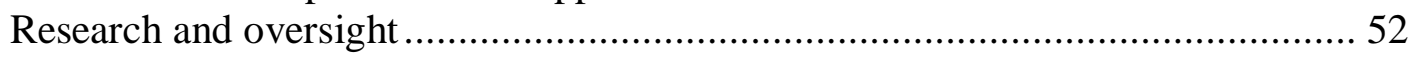

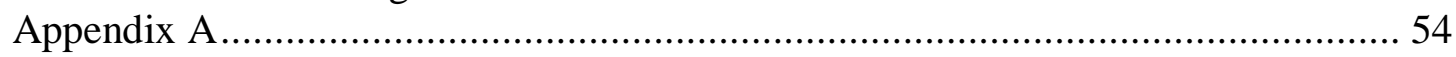

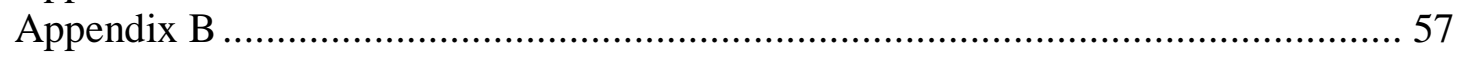




\section{ACKNOWLEDGEMENTS}

I would like to thank all those who offered constructive advice on the project, particularly Les Allamby and Brian Thompson, who provided support and feedback throughout the project. I would also like to acknowledge the assistance of the members of the research advisory group who took a keen interest in the research and provided helpful insights during the project: Marie Anderson (Deputy Northern Ireland Ombudsman) Siobhan Broderick (Northern Ireland Courts and Tribunals Service), Rt Honourable Sir Patrick Coghlin (Lord Justice of Appeal), Mark Finnegan (Special Educational Needs and Disability Tribunal / Northern Ireland Courts and Tribunals Service), Kevin Higgins (Advice NI), Louise Kyne (Citizens Advice Northern Ireland), Conall MacLynn (President of the Appeals Tribunal for Northern Ireland), Eileen McBride (President of the Industrial Tribunals and Fair Employment Tribunal), Kenny Mullan (Chief Social Security Commissioner for Northern Ireland), and Paula Stevenson (Office of the Lord Chief Justice). Thanks also to Deborah Magill for her research assistance on the project. I gratefully acknowledge the Nuffield Foundation which has funded this research, and Law Centre (NI) which has, once again, commissioned and facilitated the research. Finally, and most importantly, I would like to thank those who gave up their time to participate in interviews, focus groups and questionnaire surveys, and without whom the research could not have been completed. This report and its recommendations are the responsibility of the author alone.

\section{THE AUTHOR}

Gráinne McKeever is a Senior Lecturer in the School of Law, University of Ulster, and Vice-Chair of the Management Committee, Law Centre (NI). The report is written in the author's capacity as an academic.

\section{Gráinne McKeever}

School of Law, University of Ulster, Shore Road, Newtownabbey BT37 0QB

g.mckeever@ulster.ac.uk 


\section{EXECUTIVE SUMMARY}

In June 2010 Law Centre (NI) published a report, Redressing Users' Disadvantage: Proposals for Tribunal Reform in Northern Ireland, by Gráinne McKeever and Brian Thompson, which was funded by the Nuffield Foundation. The report set out a number of recommendations for tribunal reform in Northern Ireland, one of which was to conduct research into user awareness and experience of advice, information and support services. Law Centre (NI) obtained further funding from the Nuffield Foundation to progress this recommendation and commissioned this report which is focused on understanding the information, advice and support needs of users prior to their tribunal hearing. As with Redressing Users' Disadvantage, this study is a small qualitative study which focuses on three tribunals: Appeal Tribunals (social security and child support), Industrial and Fair Employment Tribunals (I/FET), and Special Educational Needs and Disability Tribunals (SENDIST). Semi-structured interviews were conducted with a total of sixteen tribunal users from across the three tribunals, along with a further five interviews with tribunal staff and departmental officials. A focus group with eight specialist legal and lay advisers was also held, and questionnaire responses were received from an additional six advisers. Overall, 35 individuals provided direct input into the research.

\section{Key findings}

\section{Awareness of support services}

Tribunals routinely provide users with a range of written information, including literature on their dispute rights, as well as information on the tribunal and the documentation necessary to lodge a case with the tribunal. In addition, tribunal staff provide a critical form of support for users in responding directly to user enquiries and clarifying the information that tribunal users receive. While tribunal literature and staff also provide users with a list of sources of further information, advice and support, a recurrent finding of this research was that users still did not know where to go for advice. Users did not access support in a systematic manner but tended to become aware of different advice sources incrementally and by chance.

\section{Barriers to accessing support}

The research found that users do not always appreciate that the issues they are contesting, claiming or responding to are legal as well as factual, and where this is the case users do not identify a need to seek advice on the legal issues, or look for advice through legal channels. Dealing with a dispute over special educational needs provision or incapacity for work may simply be seen as another manifestation of an ongoing problem in a person's life, rather than as a separate legal problem. One consequence of this is that users may go to the support person or organisation they have previously used, for example a health care professional, to get further advice or supporting evidence. Where users do not understand the legal basis of their decision, they may not understand what the evidence must establish for their case to be successful - a difficulty which is compounded where those providing the evidence also fail to understand the issues under debate - and they can fail to appreciate that they may require specific support to address this legal issue. This highlights the basic question that users may not ask themselves (and are often not equipped to answer) 
which is 'what is the legal issue?' Where users were able to access advice and support they were better able to address this question but there was a shared frustration among all of the participants in the research that the capacity of support organisations to support users could not always meet demand.

The research also found that written information to support users could often be problematic in terms of its complexity and volume and, in some cases, the source of the information. Within this research, users found I/FET and SENDIST information more accessible than social security appeal tribunal information. This is due in part to the lower levels of confidence social security appellants have in their oral and literacy skills but also appears to be connected to the absence of a 'Plain English' vetting process for social security appeal tribunal information, which I/FET and SENDIST information are both subjected to. Barriers to support increased where users had a range of personal vulnerabilities, creating a category of users who are particularly hard to reach.

\section{Experience of support services}

The findings of this report echo those of Redressing Users' Disadvantage that, where users are able to access support organisations, they find the support they receive to be very helpful. The main benefit in accessing advice was found to be in providing a means of resolving disputes at the earliest stage. This included helping users to avoid the dispute by making sure the initial decision was right from the outset, understanding the basis of the initial decision and identifying a range of ways to challenge a decision. The research also found that users needed support in understanding and complying with tribunal rules and procedures and in managing their expectations of the tribunal hearing. In addition, users identified a need to have support to redress an inequality of arms between the parties to the hearing. Advisers were also seen to play an important role in facilitating an alternative resolution and helping users avoid the need for a tribunal hearing. Users consistently regarded personal contact with advisers and support workers as very important.

\section{Key recommendations}

The findings of this research point to the continued need to put users at the centre of Department of Justice policy, and the policy of relevant sponsoring Departments, through the implementation of proportionate dispute resolution processes. The recommendations of this report are accordingly structured to align with the progressive stages of proportionate dispute resolution.

\section{Recommendation 1}

Users must be the focus of the Department of Justice and its policy and executive units in relation to tribunals and administrative justice. Where tribunals are not administered by the Department of Justice, tribunal users must be the focus of their sponsoring Departments.

\section{Initial decision making}

There is evidence that users struggle to understand what information first instance decision makers require and to understand why the initial decision was made. Where this is so, users will struggle to construct a valid case through all stages of a dispute resolution process. Compounding this problem is the evidence of a working culture 
within pockets of relevant Departments that prevents disputes being resolved at an early stage by initial decision makers.

\section{Recommendation 2 \\ Improve first instance decision making, ensuring that staff implement Departmental policy to resolve disputes at an early stage. This includes making sure users understand what information they are required to provide to decision makers and that they understand the reasons for the decision that has been made.}

\section{Written information}

Users are not knowledgeable about their rights and how to enforce them, or how to get support to help them raise or respond to a dispute. Not all forms of support that have been developed to assist users have been successful and it is clear that written information for users is not a panacea. For too many users understanding written information is fraught with difficulties, and users are not familiar enough with available sources of information and ways in which they might be accessed.

\section{Recommendation 3 \\ Improve written information for users to advise them of their rights and obligations, and options for dispute resolution. This could involve further evaluation of good practice such as the easy-read guide produced by the Tribunals Service; utilising Plain English processes; providing short summaries of appeal submissions, in addition to the submissions; and working with a full range of stakeholders who provide support to users.}

\section{Recommendation 4}

Develop effective methods of obtaining feedback from users on the efficacy of the information.

\section{Recommendation 5}

Identify, in consultation with users and relevant stakeholders, including departmental and voluntary sector bodies, the ways in which users could best access written information.

\section{Video information}

Users continue to be intimidated by the prospect of a tribunal hearing and require better forms of support to familiarise themselves with what a tribunal hearing entails. Not all tribunals have public hearings and not all users are able to attend tribunal hearings in advance of their own to understand what a hearing is like. The use of video information would be helpful for users. Issues of cost and the type of tribunal hearing that could be featured in video information could be addressed by drawing on other models of video information.

\section{Recommendation 6}

Departments with responsibility for tribunals should continue to explore the potential of providing video information for users on dispute resolution processes and what these processes require of users. 


\section{Recommendation 7}

Tribunal Secretaries should document the nature of calls to tribunal staff to establish what users most request assistance with and whether patterns of need vary.

\section{Early advice consultations}

The main finding of this research was on the need to prioritise early advice for tribunal users, providing support that enables users to identify the legal issue under dispute. This support should be provided as soon as users raise or respond to a dispute. In the main, individual and personal contact remains the best option for supporting users. The cost of facilitating this needs to be fully understood, as does the cost of not providing early advice.

\section{Recommendation 8}

The Department of Justice should conduct research on the cost-effectiveness of providing tribunal users with an initial personal advice session at the outset of their dispute, with advisers who are equipped to advise on the specialist issues dealt with by tribunals and to identify other justiciable problems the user may be experiencing. Funding for this research should come from government Departments with policy responsibility for tribunals and for the issues dealt with by tribunals.

\section{Recommendation 9}

This research could usefully include a pilot of pre-hearing support sessions for users of one of the smaller tribunals, using the pilot to evaluate the specific benefits of pre-hearing support.

\section{Facilitating referrals for users}

There is a need for a co-ordinated approach in the delivery of relevant services to properly support users and avoid a continuous process of onward referral without resolution.

\section{Recommendation 10}

Related departmental, statutory and voluntary sector services that deal with users should work collaboratively to ensure that referrals to and from their organisations are dealt with efficiently and effectively. The Department of Justice should work with these organisations to identify where the gaps are in dealing with referrals, so that resources may be allocated in the most focused way.

\section{Innovation in the provision of support}

While traditional methods of providing support for users continue to be important, there remain users who are not supported by these methods. For these users the importance of a proportionate dispute resolution process is critical in preventing problems arising and dealing with them at the outset. Where problems persist, additional innovative approaches, including the provision of public legal education, need to be adopted to support hard-to-reach users. 


\section{Recommendation 11}

Identify and develop innovative models of providing information and support to tribunal users beyond the traditional advice models.

\section{Recommendation 12}

Identify and develop methods of providing public legal education for users and for those outside the advice sector from whom users may seek advice, such as health care professionals and politicians.

\section{Research and oversight}

This research has been able to identify a number of key issues but a considerable research gap remains that needs to be addressed. A systematic and coherent approach is required to enable the strategic progression of the key recommendations of this report and those contained within Redressing Users' Disadvantage. Consequently, a structure needs to be put in place to oversee the organisations involved in delivering administrative justice. This would help to champion the cause of tribunal users and ensure they remain at the centre of policy and legal developments. This report adopts the recommendations for an oversight body made by Brian Thompson in his review of Northern Ireland tribunal structures.

\section{Recommendation 13}

Further research should be conducted with a representative sample of tribunal users to understand the experiences of tribunal users in Northern Ireland.

\section{Recommendation 14}

There should be an inter-disciplinary advisory body established to contribute to the oversight of tribunals and administrative justice but this body should be connected to other advisory bodies for civil and family justice so as to reflect the system approach which acknowledges the links, overlaps and gaps amongst the components of the legal system and to counteract undue focus on the criminal justice system.

\section{Recommendation 15}

This body, the Northern Ireland Civil and Administrative Justice Advisory Committee (NICAJAC) should be chaired by the Lord Chief Justice and have reporting to it sub-committees for Civil, Family and Administrative Justice. The chair and one member of each sub-committee shall be members of the committee which will meet bi-annually. The sub-committees could meet quarterly. The membership should include judges and legal practitioners, and in reflecting users' interests at this peak level, advice bodies and academics engaged in research. The Northern Ireland Ombudsman should be an ex officio member of the Administrative Justice sub-committee and possibly of the main committee.

These recommendations present a challenge to those tasked with supporting tribunal users and providing them with the pre-hearing information and advice that they need, but the findings of this research point to a need for action, to build on existing good practice and develop further and better forms of support for users. 


\section{INTRODUCTION}

1. In June 2010, Law Centre (NI) published a report, Redressing Users' Disadvantage: Proposals for Tribunal Reform in Northern Ireland, by Gráinne McKeever and Brian Thompson, which was funded by the Nuffield Foundation. ${ }^{1}$ The report provided an insight into users' experiences of three different tribunals in Northern Ireland, and established the issues surrounding the reform of Northern Ireland tribunals, including arrangements for the oversight and accountability of these tribunals. The report also made a series of recommendations for tribunal reform in Northern Ireland (see Appendix A), including recommendations to support users in challenging decisions before tribunals.

2. At the conference to launch Redressing Users' Disadvantage, the Minister for Justice, David Ford MLA, launched the Departmental Tribunals Modernisation Strategy and Action Plan which included commitments to improving user information and advice about tribunals, and gathering information from users through a survey and by creating user groups for each tribunal. ${ }^{2}$ These points were among the report's recommendations. The report also recommended the creation of an Administrative Justice Steering Committee to map the administrative justice system in Northern Ireland and consult on structural changes to tribunals. The Minister has established a Tribunal Reform Reference Group in association with the Lord Chief Justice and the Northern Ireland Ombudsman, which will map the administrative justice system and begin to develop options for reform. ${ }^{3}$

3. While the Departmental Action Plan is welcome, as is the Ministerial Reference Group, these two measures cannot deliver the range of recommendations made in Redressing Users' Disadvantage. In recognition of this, Law Centre (NI) made an additional application to the Nuffield Foundation which awarded funding to take forward two central recommendations within the report. The first, which this report deals with, is designed to respond to recommendation 6 in particular: that there should be further research into tribunal users' awareness and experience of the associated advice, information and support services of tribunals in Northern Ireland. Funding has also been awarded to take forward recommendation 17: to consult on the specific structural needs of tribunal reform in advance of tribunal legislation. This is being conducted by Brian Thompson. Both research initiatives have been brought within the remit of the Tribunal Reform Reference Group.

4. This report is therefore focused on the needs of users in Northern Ireland prior to their tribunal hearing. Redressing Users' Disadvantage identified that users face challenges at successive points, and that a significant barrier for many users was in getting to a hearing: first, in recognising their right to challenge a decision and second, in being able to bring the challenge forward to a tribunal. This research seeks to identify what users regard as the benefits of having support prior to their tribunal hearing, and to understand why some users are not able to access this

\footnotetext{
${ }^{1}$ Belfast: Law Centre (NI).

${ }^{2}$ Northern Ireland Courts and Tribunals Service, Tribunals Modernisation Strategy and Action Plan 2010-11 (June 2010).

${ }^{3}$ Department of Justice Press Release, "Ford includes tribunal reform in plans to reshape the Justice system", 23 June 2010.
} 
support. Accordingly, this report is structured as follows. The report briefly reviews the methodology employed and presents the findings of the research, focusing on establishing the value of support to users, the ways in which support is provided to users and the barriers users face in accessing this support. The report identifies ongoing improvements to the support users receive before making recommendations on how this support might be developed to best assist users.

\section{Methodology}

5. This report is based on a small qualitative study that aims to establish some insights into the availability and adequacy of information and advice that is provided to tribunal users. As with Redressing Users' Disadvantage, this study focuses on three tribunals: Appeal Tribunals (social security and child support), Industrial and Fair Employment Tribunals, and Special Educational Needs and Disability Tribunals. The rationale for this is that the first two tribunals constitute the largest tribunals in Northern Ireland in terms of caseload and therefore provide an insight into access to information and advice for the largest group of users, and the third tribunal represents one of the smallest tribunals in Northern Ireland, so its inclusion helps ensure that the needs of users of a smaller tribunal are not engulfed by those of the larger tribunals. In addition, using the same tribunals as in the first report allowed the author to develop the findings from the first report, helping to strengthen findings and conclusions in this report.

6. For this report, semi-structured interviews were conducted with tribunal users from each of the tribunals: eight social security appellants, four Industrial/Fair Employment (I/FET) claimants/respondents, and four Special Educational Needs and Disability Tribunal (SENDIST) appellants were interviewed, giving a total of sixteen user interviews. The views of user representatives were obtained through a focus group discussion and responses to written questionnaires. Eight specialist legal and lay representatives who provide advice and representation to appellants, claimants and respondents of each of the three tribunals, and officials from the Equality Commission and the Labour Relations Agency (LRA), participated in a two hour focus group discussion. A questionnaire reviewing similar themes as the focus group discussion was circulated to other representatives and six responses were received. Interviews were also conducted with those employed within the three tribunals and within the Departments with policy control over social security and child support appeal tribunals and Special Educational Needs and Disability Tribunals. The relevant official within the Department of Education was on leave during the fieldwork for this report and so was not able to participate in an interview. In total five interviews were conducted with this stakeholder group. Overall, 35 individuals provided direct input into the research.

7. As with Redressing Users' Disadvantage, this does not constitute a representative sample of tribunal users and stakeholders in Northern Ireland and the research is not intended to provide a categorical account of the experiences of all tribunal users. Consequently, there remains a considerable research gap in understanding the experiences of tribunal users in Northern Ireland that still needs to be addressed. Nevertheless, this report does provide some useful insight into the issues identified as critical by this group of users and stakeholders and, together with Redressing Users' Disadvantage, provides a more informed view of users' awareness and experience of pre-hearing information, advice and support services. 


\section{RESEARCH FINDINGS}

\section{Section 1: Awareness of support services}

8. In order for support services to be of value to users, users need to be aware of the support services and the value they can provide. This is not simply a matter of informing users of the existence of a particular tribunal to which they may bring a challenge, but involves making users aware of how to resolve their problems as quickly as possible; to prevent them from resorting to a tribunal where this can be avoided, while still providing suitable support for those whose problems require a tribunal hearing. In other words, there are different stages of problem solving and users can receive support at all of the different stages. Discussions with advisers revealed that there are three main stages to the advice giving process:

Stage 1: advice on the steps to enforce rights and avoid tribunal proceedings (including advice on alternative means of resolving disputes);

Stage 2: procedural advice on how to initiate or respond to tribunal proceedings (including advice on timeliness);

Stage 3: advice on how to run a tribunal case (including advice on the legal aspects of the case).

Users may approach advice organisations at any of the three stages, but where users approach advisers at stage one they may not need to progress through stages two and three. In order for this to happen, users need to have some awareness of relevant advice, information and support services to allow them to resolve their dispute in the most appropriate and timely way.

\section{a. Written information for users}

9. Individuals who wish to consider taking or responding to a case at tribunal are routinely issued with written information from the respective Departments and/or tribunals. This is designed to provide them with a basic outline of their right to challenge a decision, or respond to a complaint, and of the procedures that are adopted by the relevant tribunal.

10. Social security appellants are issued with a letter from the Social Security Agency. The letter informs them of the Agency's decision on their claim for a particular benefit, and also informs them of their dispute rights, including their right to request a reconsideration of the decision. Where users exhaust or decline this right, further information on appeal rights is provided by the Department for Social Development (DSD) in form GL24. ${ }^{4}$ This form also identifies that 'customers' may be able to access further information and advice from organisations like CAB. ${ }^{5}$ When their appeal is received by The Appeals Service (TAS), users are sent the Information Leaflet, a thirteen page document that covers information on the nature and process of tribunal hearings. ${ }^{6}$ The

\footnotetext{
${ }^{4}$ Available to download from the NI Direct website, and via the DSD website at: www.nidirect.gov.uk/if-you-think-our-decision-is-wrong-gl24.pdf

${ }^{5}$ On page 15 of a 19 page document.

${ }^{6}$ Available to download from DSD website at: $\underline{w w w . d s d n i . g o v . u k / t a s ~ i n f o r m a t i o n ~ l e a f l e t . p d f ~}$
} 
Information Leaflet from TAS includes a section on 'Where can I get help' which gives an indicative list of organisations that may be able to provide advice and assistance. $^{7}$ All of these documents are available to download from the DSD website, and links to this website are available from the Northern Ireland Courts and Tribunals Service (NICTS) website under the link for The Appeals Service. No additional online material is available, including video material about the tribunal.

11. In relation to SENDIST appellants, SENDIST has secured agreement with the Education and Library Boards (ELBs) to provide an information leaflet to parents on appeal rights when the Board issues its decision letter to parents. ${ }^{8}$ This information contains details about SENDIST, including contact details. When users contact the Tribunal to enquire about appealing the Board's decision they are issued with the "How to Appeal Booklet". Users register their appeal, using the form issued by the Tribunal, and are then provided with further information advising them how they can put their case together. It can be noted that, although the physical and email addresses of the Tribunal are provided on all of the different information leaflets, not all of the leaflets include the telephone number of the SENDIST Secretariat. The written information from SENDIST does not currently signpost users to legislation that may be relevant to their appeal, or to potential sources of advice. New forms are currently being prepared that will provide the telephone number for SENDIST as well as signposting users to relevant legislation. The website for SENDIST is on the NICTS website, and it provides a brief guide to parents on SENDIST. Documentation is not available to download from here, which limits the availability of information, a limitation that is recognised by SENDIST staff. While legislation cannot currently be accessed directly from the SENDIST website, NICTS aims to upload relevant legislation by the end of September 2011. As with TAS, there is no video information available about the tribunal.

12. I/FET users are in a slightly different position in that disputes within this tribunal are party vs party, rather than party vs state as in the other two tribunals. For this reason, there is no standard letter that is issued to individuals who may be unhappy with an employer's decision, advising them of their dispute rights. There is, however, an information pack that is available from the Tribunal (and from other sources) for both claimants and respondents. This contains the claim/response form to an Industrial/Fair Employment Tribunal, guidance notes for the completion of the relevant claim/response form, a procedural booklet and employer/employee focused information on statutory dispute resolution. ${ }^{9}$ The procedural booklet provides general advice to claimants on 'Getting help with a claim' from a trade union, voluntary sector advice agency, the Labour Relations Agency (LRA) or the Equality Commission, and the possibility of applying for

\footnotetext{
${ }^{7}$ On pages 4-5 of a 13 page document.

${ }^{8}$ SENDIST, Special Educational Needs and Disability Tribunal: A Brief Guide for Parents

9 "Making a claim to an Industrial Tribunal and/or The Fair Employment Tribunal" (revised June 2009) and "Responding [to] a claim to an Industrial Tribunal and/or The Fair Employment Tribunal" (revised June 2009)
} 
Legal Aid to obtain advice, but not representation, in connection with a claim. ${ }^{10}$ Respondents are advised that they may represent themselves or obtain representation from "for instance an employers' organisation or a solicitor", and of the availability of conciliation services through the LRA. A list of 'useful contacts' is provided at the end of the booklet, with contact details of relevant organisations. ${ }^{11}$ Claimant and Respondent information packs also contain a booklet on resolving disputes at work, and reference is made here to the booklets in the Employment Rights series published by, and available from, DEL. ${ }^{12}$ This information is also available online from OITFET, but no additional information on how the tribunal operates, including video information, is available.

\section{b. Responding to direct user enquiries}

13. All of the tribunals noted a steady flow of users contacting tribunal staff. The reasons for these enquiries varied, and tribunal staff would not necessarily record the nature of the enquiries made, so it is difficult to discern a particular pattern of reasons why contact is made, and any variations within this pattern over time. Staff in OITFET, however, noted that enquiries are usually fed back to the Secretary, particularly those that involve a complaint or an enquiry about tribunal procedure. Nonetheless, in all of the tribunals, users consistently contacted the relevant tribunal to request clarification of information that had been provided, either because users had not read or had not understood the information. In any event, it was common practice for tribunal staff in each of the three tribunals to talk users through the written information, to assist with their understanding of this information and to refer them back to the written information:

Tribunal staff: "it's kind of in the information leaflet but if they do phone it will be gone through."

14. User enquiries range from general issues such as the procedures for taking a case and what to expect at the tribunal, to more specific issues such as the date of the hearing and when a decision might be issued. Users will also make enquiries to the tribunals about potential sources of information or assistance, or they will be signposted to potential sources of support by Tribunal staff where this seems appropriate, for example where the user query relates to 'legal' advice which tribunal staff are not able or authorised to answer. OITFET and SENDIST staff also stated that the sources of support they provide for users would include sources of online information and advice. It was noted that the provision of information on further sources of advice and representation had to be balanced against the assurance that tribunal users are not required to have representation. Tribunal staff made particular mention of the need for users to be able to access the relevant legislation. While there are currently no direct links to legislation

\footnotetext{
${ }^{10}$ At p14 of a 68 page booklet.

${ }^{11}$ These include Citizens Advice Bureaux, the Equality Commission, the Labour Relations Agency, the Department for Employment and Learning (Employment Rights Division and Redundancy Payment Services), the Health and Safety Executive, Law Centre (NI), National Minimum Wage enquiries freephone number, and Northern Ireland Legal Services Commission.

12 Employment Rights guides are available from the Department for Employment and Learning website at: www.delni.gov.uk/index/publications/pubs-employment-rights/erbooklets.htm.
} 
from the SENDIST webpages on the NICTS website this was identified as an ongoing project for SENDIST. Where possible, staff would advise users how they might access the legislation online. Where I/FET users are not in a position to access online sources, OITFET would help them to get copies of the legislation, although this was articulated as being part of OITFET's customer service role rather than the duty of tribunal clerks, the distinction appearing to relate to what clerks provide users with as a courtesy rather than as an obligation.

15. It was clear that tribunal staff provide a critical source of support for tribunal users. ${ }^{13}$ Staff in each tribunal recognised that this may be in the form of general assistance, rather than in their role of providing tribunal specific information to users:

Tribunal staff: "Sometimes you're more just like a shoulder to cry on than anything else, but if you're able to offer that opportunity to them then that in itself, I think, can help."

However, while staff were happy to discharge this role, there was a difficulty in having to draw the line between support and legal advice, with staff being clear that the provision of legal advice was absolutely beyond their competence:

Tribunal staff: "it's a fine line between trying to be helpful and bordering into the advice area ... So it's very, very difficult for the staff where they want to be helpful and want to be seen to help people with procedures, not actually advising ..."

Tribunal staff: "We have had some very difficult interactions with [users] who believe we're deliberately being ... vague. But they can't understand that we can't be their representative."

16. Overall, staff recognised that they had a role to play in responding to user enquiries and that this often involved providing reassurance, for example by letting users know that Tribunal Chairs can clarify points of uncertainty that clerks are unable to deal with, or by making users aware that they can visit the tribunal in advance of their hearing. I/FET users are able to sit in on other cases, and staff appeared to regularly make users aware of this possibility. Social security appeal tribunals are also public hearings and available to anyone to attend. This is done with the approval of the Chair hearing the appeal and the appellant on the day, but in reality appellants rarely avail of this opportunity. The tribunal's written information does not make users aware of this possibility and it is not clear whether tribunal staff routinely inform users of this. SENDIST hearings are in private. Users may familiarise themselves with the layout of the tribunal when hearings are not taking place but they are not permitted to attend another appellant's hearing.

\footnotetext{
${ }^{13}$ The NICTS Customer Service Questionnaire 2011 summary notes that $88 \%$ of survey respondents who contacted Tribunal office staff found them to be polite and 91\% said they were helpful: NISRA, Tribunals: Customer Service Questionnaire 2011, Section 3.
} 


\section{c. Where to go for advice?}

17. Users in Northern Ireland can access information, advice and support from a wide range of bodies, including statutory and voluntary sector organisations (see Appendix B) as well as online from websites such as NI Direct. Nevertheless, a recurrent finding among all of the groups who participated in this research was that users simply did not know where to go for advice. This included those who had received written information which signposted them to various sources of advice, suggesting that this method of information delivery is not effective for some users.

18. While there was some variation in the extent to which users indicated they needed support - some needing less than others - where users wanted support but did not know how to access it this became problematic. One user found the lack of information about "who to go and see" for advice to be the most difficult thing about preparing for his case. Others echoed the problem of not knowing and not being told who could provide advice on their case:

Social security appellant: "I probably didn't know who to go to ... There's no help ... they don't say use this contact or this."

Although there was a general knowledge of the services offered by Advice NI, $\mathrm{CAB}$ or other voluntary sector organisations and the possibility (in theory at least) that these organisations could have provided support, many users tended to reflect on this fact after their hearing rather than before it.

19. Finding an individual or organisation that could provide support often involved an element of luck, sometimes with help from healthcare professionals who were aware of the user's case, through talking to friends or colleagues in similar situations, or through general internet searches:

SENDIST appellant: "I mean, it was totally by chance. A lot of it was just, sort of, searching and coming across things. A lot of it was just luck."

SENDIST appellant: "I came across the Children's Law Centre by accident through work ... Just pure chance ..."

SENDIST appellant: "just by good luck we seemed to get the right information, I think, at the right time..."

For users in this position, the process of accessing support tended to be incremental rather than systematic, getting "wee bits of advice" from talking to different people, and gathering information through this ad hoc approach. One SENDIST user described seeing a poster for an advice organisation on the wall of a local children's therapy centre which prompted her to seek advice from this organisation. Prior to this, the user had gone through the Yellow Pages to get contact details of organisations that deal with education and/or autism. This approach highlights a further difficulty for users in knowing where to go for advice, namely the lack of awareness that a legal entitlement is at issue, and that 
advice on the legal issues may be required. This is a major barrier to accessing support and is discussed further below, in section 2 .

\section{Section 2: Barriers to accessing support}

20. As with the previous report, it is clear that there are a number of barriers faced by users in accessing support. Many of the themes which emerged in the previous report are corroborated in the current research which now examines in more detail the barriers that users face. ${ }^{14}$

\section{a. What is the legal issue?}

21. Redressing Users' Disadvantage highlighted the advantages of specialist advice, whether legal or lay, to the user and to the tribunal. The value of this support stems from the ability of advisers to understand the specific legal issues in the case and to advise on them. Users do not always appreciate that the issues they are contesting, claiming or responding to are legal as well as factual, and where this is the case users do not identify a need to seek advice on the legal issues, or look for advice through legal channels. Dealing with a dispute over special educational needs provision or incapacity for work may simply be seen as another manifestation of an ongoing problem in a person's life, rather than a separate legal problem. For many users, their case is a personal story that they need to prove: one user described the tribunal as simply asking a few personal questions about "your average ailments", and so believed that bringing in "somebody who has a bit more knowledge ... in what the law says" would not have been helpful. Another saw the social security appeal tribunal as the stage prior to a legal case, with appeal to the Social Security Commissioner the stage at which it became legal and required the involvement of a solicitor. Not surprisingly, perhaps, this appellant noted after his hearing that he found the tribunal to be "very legalistic".

22. Social security and SENDIST appellants tended to prioritise advice on the 'medical' aspects of their case, whether because of their relationship with their health provider whom they regarded as the 'go to' person for any health related problems, or to further evidence the veracity of their claims regarding the nature and impact of health conditions. While such evidence is often necessary, where users do not understand the legal basis of their decision, they may not understand why the medical evidence is required and what the medical evidence must establish for their appeal to be successful. This difficulty is compounded where the medical experts also fail to understand the issues under debate:

Social security appellant: "'This [Employment and Support Allowance] is a totally new thing and the doctors don't know enough about it ... They don't have a clue."

\footnotetext{
${ }^{14}$ Other research on barriers to users is also borne out here. See in particular Michael Adler and Jackie Gulland, Tribunal Users' Experiences, Perceptions and Expectations: A Literature Review, Council on Tribunals, 2003, Hazel Genn, Ben Lever, Lauren Gray with Nigel Balmer and National Centre for Social Research, Tribunals for Diverse Users, (DCA Research Series 1/06, 2006) available at: www.dca.gov.uk/research/2006/01 2006.pdf.
} 
There is a need for the evidential gap to be identified: medical evidence that does not meet the evidential need of the user is of limited value. This points to a need for those meeting the evidential gap to understand what the evidence is required to demonstrate, and to be trained and informed in this regard as necessary.

23. Where users are unaware that they have legal rights, they are also likely to be unaware of the possibility of pursuing those rights by disputing the decision they disagree with. This lack of awareness may be perpetuated by personal vulnerabilities of the user (an additional barrier to accessing support, discussed further below) and by a lack of communication between decision makers and users about what rights users have. For SENDIST users, difficulties in communication between schools, ELBs and parents created an immediate problem:

Focus group participant: "the first point of communication is between parent and school, and if that breaks down and the parent isn't happy with what the school has provided, the school is not going to say, oh, go and get somebody, get advice from the Children's Law Centre. They will try to take control of the child's provision and tell the parent, we're doing this and we're doing that. So the parent is disempowered at an early stage, and doesn't know that they can seek advice ... Very often with the parents, the school knows best: 'the school is going to do their best for my child'. The school might be trying to do their best but have limited resources, or they might have a ... poor ethos in relation to equality disability issues."

SENDIST appellants also raised the issue of 'misinformation' from the ELBs, which undermined their legal rights:

SENDIST appellant: "the letter they sent me out saying they weren't assessing my child didn't have my right to appeal on it. It was only when I contacted the Children's Law Centre, he said, you've a right to appeal. It doesn't say this in the letter ... So are things like that mistakes, or are they things that they're doing to deter people ... from appealing?"

SENDIST appellant: "Who is making [the Board] accountable for promising me things that they couldn't promise, you know? Making promises that they couldn't keep to get me to withdraw my appeal ... I sat in a meeting with the Board, and she said, we'll give you this, this and this. And the Literacy Support will kick in September, so you can withdraw your appeal ... I did contemplate withdrawing then. It was only [because] I made a phone call to the Head of Literacy Support, who said, I made no such promise ... she was never in a position to offer you this, because I am Head of Literacy Support and I would never promise a child, because there's a waiting list and this is how it works, blah, blah."

SENDIST appellant: "Even though the Education Act is there, the Board still do completely different things, and the Board would have you believe ... if you 
were silly enough, they would have you believe, that's not actually a legal or a law-abiding, you know, document. This is our law, and we can do it or bend it whatever way we like."

In these scenarios, the issue is not simply that SENDIST users do not know what their legal rights are, but that they may have been given inaccurate information which prevents them from understanding their legal entitlements. The barriers for users in accessing support to assert their rights under these circumstances are significant.

24. While some users may be unaware of their rights, others may have a general sense of grievance and an accompanying sense that they should be able to challenge this grievance. As Redressing Users' Disadvantage identified, the difficulty for these users may be in translating their sense of grievance into a justiciable issue that the tribunal can adjudicate on. This again relates back to the basic question that users may not ask themselves (and are not equipped to answer) which is 'what is the legal issue?'

25. The problem appeared particularly prevalent for social security appellants and I/FET claimants. Social security appellants consistently struggle to understand the basis of the Department's decision and so do not understand what the potential grounds for challenging the decision are. Their understanding is not helped by the Appeal Submission, a large body of tribunal papers (which can run beyond one hundred pages), which one appellant referred to as "War and Peace". While the information appellants need is in the Appeal Submission, it is not in an accessible format, and so users also miss out on this opportunity to understand the legal basis of their case:

Focus group participant: "The Appeal Submission that they get is both the most helpful and the most important document that they receive, it is anything and everything really, that tells them how the decision was reached, in their particular case, but for them to understand it, they're simply coming from the point of view, my doctor says I'm not fit for work, [the Department's] doctor - the big doctor - says I am, my doctor knows me better than the big doctor, QED. And you say, no, it doesn't work like that, because your doctor doesn't know the test that has been set up by the government and you have got to score points under these precise categories..."

26. The failure to appreciate that a legal test must be satisfied is an ongoing difficulty for users; this is clearly one of the main advantages in getting access to prehearing advice. It may be argued that the positive side of this for social security appellants is that this lack of knowledge does not prevent them from lodging an appeal, since their right to appeal is on the simple basis that they disagree with the Department's decision. While this may mean that cases without prospect of success are appealed, requiring time and resources from the tribunals in explaining to users why their case cannot succeed, it also means that a lack of legal knowledge does not prevent users from attempting to progress their rights. For 
this reason, it may also be argued that this situation is preferable to the situation that I/FET users find themselves in, where the lack of legal knowledge can have a more detrimental impact on their rights. As with other users, I/FET claimants may not understand that there must be a justiciable issue within their grievance:

Tribunal staff: "I think that finer differentiation confuses people. You know, they think if my employer's treated me badly, I've a right to make a claim. Well, you're sort of trying to get down to, well, what right does he actually breach ...?"

27. There is, however, a further difficulty for this user group. Claimants alleging a breach of employment rights are required to identify at the outset what that breach is, and a failure to identify the correct legal basis of their claim can be very problematic. In simple terms, claimants may not make the claim that they could be making, or not make the claim properly, and so their justiciable claim is not identified and cannot be determined. In some cases the correct claim may be identified by Chairs in case management discussions. However - leaving aside the fact that Chairs cannot provide advice to users - there is the practical problem that by this stage the time limit for making the correct claim may have passed leaving claimants time barred. Cases of this nature would seem to be particularly unfortunate since claimants may have attempted to address the basic question of 'what is the legal issue' but are simply not equipped to answer it. ${ }^{15}$ For these users, specialist advice on the relevant justiciable issues is required.

\section{b. Lack of available advice}

28. One of the methods used by Departmental and tribunal staff to deal with the difficulties faced by users in progressing their disputes has been to signpost users to relevant advice organisations. Providing a list of possible sources of help has become a standard response of tribunal staff to user enquiries that are beyond their remit. As noted above, this includes voluntary sector organisations, like Advice NI or $\mathrm{CAB}$, and specialist organisations dealing with specific issues users may have, such as the Equality Commission or Law Centre (NI). The difficulties, however, arise where these advice organisations are unable to help users:

Social security appellant: "The problem is [CAB] were snowed under ... I would have loved if they were here ... They gave me some advice but ... I went through a lot of stuff myself ..."

Social security appellant: "[CAB advice] was helpful but ... there was a queue of people down there waiting to get help ... there wasn't enough people, and you had to wait for, like, an hour and a half to see somebody."

\footnotetext{
${ }^{15}$ Redressing Users' Disadvantage also bears out the difficulty for users in understanding the legal issues. For example the report notes that "unrepresented claimant faced a considerable challenge in dealing with respondent requests for 'further and better particulars', with claimants then being tied to their responses as legal pleadings despite not having understood them properly or responded properly. These requirements were seen as a contributory factor in cases being dropped": at $\mathrm{p} 45$.
} 
Social security appellant: "it takes so long to make an appointment [with $\mathrm{CAB}]$, it takes so long to get in ..."

This frustration was shared by those working within the tribunal system, trying to support users:

Tribunal staff: "Very, very difficult, that whole area of not having advice ... They'll come back: 'oh, well, you know, I've been to the Equality Commission and they've said they're not going to represent me. So where do I go from here?' What do you tell them? ... And then you get into the realms of, you know, really there's very little we can do for you. It's really a matter for you how you proceed. And it's not very satisfactory for them, and it's certainly not very satisfactory for us ..."

Tribunal staff: "The disadvantage of the [procedural booklet] is that it doesn't meet the expectations. People are asking for a procedural booklet, what they really want to know is: give me advice on how to take my case ... [W]e can tell them how to make a claim to the tribunal, but that's not what they're asking. It's do I have a claim? What do I need?"

Tribunal staff: "I think our biggest bugbear is really ... is there somewhere that we would know that if we sent people looking for advice that they would get the advice they need?"

29. While there was frustration at the inability of advice organisations to meet demand - recognised, for example, where staffing levels of voluntary sector organisations were reduced due to funding cuts - tribunal staff were reluctant to recommend private firms of solicitors to users, mainly because of the cost implication for users. Representatives of advice organisations (both voluntary and statutory) were equally frustrated with the limits of their ability to support users. This was seen as resulting from a "massive increase in volume and demand" which was not being matched with a proportionate increase in funding, and so advice agencies, already operating at full capacity, have been unable to meet the increased need for their services. ${ }^{16}$

30. There are, in addition, geographical barriers for users in accessing advice organisations. Specialist advice organisations appear to be mainly located in Belfast, with some based also in Derry/Londonderry, but beyond these areas users rely on generalist advice. While this will be sufficient for some users, for others with more complex problems there is a relative lack of resources beyond Belfast.

\footnotetext{
${ }^{16}$ This corresponds with evidence of an increase in demand for legal advice in England and Wales, in particular in areas of debt, housing, welfare benefits, employment and some family law areas: see for example Ministry of Justice (2009) Study of Legal Advice at Local Level, London: TSO; Pascoe Pleasance and Nigel J. Balmer, "The Audacity of Justice: Recession, Redundancy, Rights and Legal Aid" (2010) Social Policy and Society 9: 475-488. That this is the case for Northern Ireland is also reflected in the Access to Justice Review Northern Ireland: Report which notes that, despite the strength of the advice and voluntary sectors here, there is unmet, or partially met, legal need in relation to advice and assistance in preparing for and appearing at tribunals: para. 5.31, NICTS (September 2011).
} 
Even for users who decide to pay for legal advice, the difficulty may be that solicitors firms outside Belfast are predominantly general practices and may not have the specialist expertise required to deal with complex cases of special educational needs provision or employment discrimination. This difficulty is compounded where tribunals are based in Belfast and do not sit in other locations.

\section{c. Not understanding written information and advice}

31. Given the complexity of issues and the volume of users requiring support, a considerable amount of written information and advice has been developed through different sources as a way to help users understand their rights and be guided through the different stages of their case, from the outset of a legal problem through to the adjudication of this problem at tribunal. As outlined above, Departmental and Tribunal staff employ this written material as a means of assisting users and it seems an obvious starting point for the provision of support. Nevertheless, the value of this form of support for users is not beyond question, and the research has identified that users find its complexity and volume problematic. Some users also regarded the source of the information -particularly information that comes from the Departments - as problematic.

32. Efforts have undoubtedly been made to try and make written information and advice accessible and comprehensible for users, and to understand how useful users find the tribunal information. During 2011 the Northern Ireland Courts and Tribunals Service (NICTS) conducted a customer survey of users of the tribunals which it has administrative responsibility for. The questionnaire had a $20 \%$ response rate (constituting 64 responses). In terms of overall responses to the questions, the largest number of survey respondents attended the Mental Health Review Tribunal (17\%), the Social Security Commissioner (17\%) and The Appeals Service (16\%). The questionnaire related to a different group of tribunals than those which this report focuses on, which included the Appeal Tribunal and SENDIST but not I/FETs, since NICTS does not have administrative responsibility for I/FETs. The summary of the 2011 Tribunals Customer Service Questionnaire reveals that $74 \%$ of respondents who answered questions on 'finding out about tribunals' found it easy to obtain information about the appeals process. ${ }^{17}$ In addition, the summary identifies that $85 \%$ of survey respondents felt the information they received met their needs and $79 \%$ found the information easy to understand. ${ }^{18}$ The summary does not provide a breakdown of the percentage of respondents who answered these questions (since not all respondents answered all of the survey questions), or, more critically, a breakdown of which tribunals these respondents attended and what information they were given, ${ }^{19}$ making comparisons with the findings of this research report less straightforward, particularly when only two of the tribunals are in common.

33. Overall, however, the findings of this research report are less positive than the findings of the NICTS survey appear to be in that the provision of written

\footnotetext{
${ }^{17}$ NISRA, Tribunals Customer Service Questionnaire 2011, section 2.

${ }^{18}$ NISRA, Tribunals: Customer Service Questionnaire 2011, section 2.

${ }^{19}$ NICTS has indicated that the statistical analysis of responses to the customer survey is to be made available on its website, although this was not available at the time of writing (September 2011).
} 
information across the three tribunals has not always been successful in supporting users. While this may be largely due to other barriers, including the vulnerabilities of users (explored further below) and the inability of users to understand the legal basis of their case (discussed above), the end result is that users may not get the support they require from written information and advice. The findings of this research reveal that this difficulty is particularly apparent for social security appellants, for whom information on the Tribunal itself was often incomprehensible or misunderstood:

Social security appellant: "sometimes I can read things and it doesn't lodge properly in my head ... so I don't really end up understanding, and then forget about it."

Social security appellant: "I got a big booklet from [The Appeals Service], where you have to turn up and ... but it's ... I'm not a great reader and just, things ... don't sink in properly ..."

Social security appellant: "I couldn't really understand the booklet properly ... so there could have been [useful] information in that [but] a lot of things don't register in my head ... [I]t's sort of like you and me talking, and you're ... listening to things ... it's easier to listen and think about things than read them, and reading things don't really sink in ..."

Social security appellant: "it says you can send somebody in your place, it doesn't say you can bring somebody else with you ... [Y]ou can't bring somebody else with you just to assist you, you know. I don't think you can, on this, according to them, on there anyway."

Providing information on social security entitlements - a complex and changing area of law - would therefore appear to be even more challenging, and user representatives expressed doubts about whether their clients would be able to make effective use of 'information packs' on social security law:

Focus group participant: "Our clients are far too vulnerable ... [T]hey're vulnerable ... with skills, everything. They're just disadvantaged."

34. As noted in Redressing User's Disadvantage, social security appellants tended to have very little confidence in their oral and literacy skills. This was not found to be uniformly the case with SENDIST and OITFET users. In particular, there is a view of SENDIST users as being relatively articulate and confident, and questions have been raised over whether the SENDIST client group is representative of all parents who face difficulties in accessing special educational needs provision for their children. ${ }^{20}$ If this is the case, it may, at least partially, explain why tribunal

\footnotetext{
${ }^{20}$ For example, in Redressing Users' Disadvantage a SENDIST member noted that "“[the tribunal] appears to be accessible to people who are in a position to maybe appreciate the quite complex area of law; so that, for want of a better word, it has a sort of a middle-class aspect to it.": p31. This perception accords with the profile of parent appellants in Harris and Eden's research into School
} 
information packs from SENDIST and OITFET were regarded more positively; SENDIST and I/FET users tended to find the information helpful and straightforward:

I/FET claimant: "[the information pack] told me everything I needed to know and I needed to do ... [F]or me it was helpful ... because it told me ... what I could expect ... I found it very simple to understand ..."

SENDIST appellant: "the information that I had about what the process would be, who would be there, what would be expected, you know, what the agenda sort of is for the whole Tribunal, that was all in the pack ... So ... from the Tribunal's end of things, I found that it was all covered very well. The information that was sent out ... I knew who was going to be there and what to expect when I got there. So, I mean, I found that all helpful because it helped me to sort of plan ahead and, you know, know what would be happening and who I would be speaking to. So, I found that all very helpful, the pack that came out."

35. Nevertheless, a number of users who stated that they were able to follow the information from the tribunal raised questions they felt were not answered, despite the fact that these questions were addressed in the tribunal's information. This disjuncture between the users' perception that they understood and their failure to fully understand would seem to be echoed in the views of tribunal staff who noted that users may not understand the appeal process, or the information sent to them by the tribunal:

Tribunal staff: "I can see things sometimes coming through where you look at it and you're thinking the [user] just doesn't really understand this, but it's not something that they come along to you and ask, you know, can you do that, or is this something that you can do? But just in reading maybe what they've written you're sort of thinking, well, they don't really seem to have grasped what the Tribunal can do here. It's not even so much what the Tribunal can do, but really what the process is, you know."

36. It should also be noted that SENDIST and OITFET information goes through a 'Plain English' process - with SENDIST replicating information from its sister tribunal in England and Wales which goes through a Plain English process, and DEL having signed up to a Plain English process a number of years ago - while TAS information does not appear to go through this process. This may also help explain why SENDIST and OITFET users found the tribunal information more accessible than TAS users. TAS's sister tribunal in Britain provides users with an 'easy-read version' of its document How to appeal: a step by step guide, as well as a more detailed version of this guide. The easy read version includes pictorial

Exclusion Appeal Panels: N. Harris and K. Eden, Challenges to School Exclusion (London: Routledge Falmer, 2000), and in further research by S. Riddell, N. Harris, E. Smith, J. Stead, E. Weedon and K. Wright, Dispute Resolution and Avoidance in Education: A Study of Special and Additional Support Needs in England and Scotland, Dissemination Conference, Manchester 2009. 
illustrations of various aspects of the appeal process and the hearing,. While this report does not test the efficacy of the easy-read guide with users it would nonetheless appear to be more accessible than the information currently provided by TAS.

37. Further difficulties arise in providing written information and advice on employment and education law. The resources for the former appear to be more extensive (for example the DEL funded Employment Rights series), with relatively little comparable material available on the law relating to special educational needs. Nevertheless I/FET users still struggled to find information on employment law and to properly understand and apply it to their case. One of the main reasons identified for this was that the law was too complex to be translated into simple, accessible information. Another was that there was too much information for users to be able to access.

38. The volume of information was identified by users as being problematic. As a result, they felt 'swamped' by the materials they were given and were unable to identify the salient points:

SENDIST appellant: "the tribunal was very thorough in that they sent me a whole booklet ... I didn't initially plough through it. I think that is ... a task in itself. [I]f I was going to sit down and actually take it onboard, word for word, I did find it more helpful, you know, to ring and speak to them..."

SENDIST appellant: "just having it in a bunch of other leaflets, saying you have the right to appeal, just wasn't... I just didn't feel that that was under my notice ..."

SENDIST appellant: "I just felt I had to wade through too much and, kind of, pick out what was good and what wasn't. And you know, doubting, in my head, well is this right? Am I picking the right people? ... Is this the right information, am I missing something, is there more information out there and I'm only hearing one side of the story? ... I find that too exhausting. You know, I could understand for a family going through it the first time, would have to go through all that process. I don't think you could sidestep that, first time around ... it's just too much to wade through. And as I say, I think it should just be a standard process for everybody and just, you know, this is what you do; step one, two and three and everybody does the same and everybody knows who's going to be there and who isn't going to be there. And the teams are equal."

39. Digesting large amounts of information was complicated by the fact that the users may look at the information with a narrow focus, seeking only what they wanted to find and not processing other information that was included:

Interviewer: "Was there a letter that came from the Board saying you had a right to appeal? 
SENDIST appellant: "Probably. I'm sure there was ... but there's so much stuff ... you know, there's so much that comes from the Board ... I was more looking at what the content of the statement was and ... were the provisions there for my son. And when I saw that there wasn't ... You know, when you're so frustrated with a body and the fact that, you know, the Education Board, you don't even want to, like, read every, you know, sort of, single word. You know, you just quickly look, did they do this, are they going to do something. No they're not - oh my goodness."

40. Other users also noted that the source of the information could present problems. Information that came from the body involved in the dispute, or even the tribunal service facilitating the hearing, could be regarded with suspicion or rejected:

SENDIST appellant: "Because if [the Board are] the ones that's telling me that [I could appeal], is [the tribunal] something to do with their body and I'm going to have to just fight them, but a different department of them? ... [W] henever you're in such a negative situation, I guess you just don't even see anything positive in it, if it's coming from the same body."

Interviewer: "What information did you get about the hearing?"

Social security appellant: "I didn't read it."

Interviewer: "Okay, was it a leaflet?"

Social security appellant: "It was just a couple of pages just to say, what it was ... I threw it in the bin."

Interviewer: "Okay, why?"

Social security appellant: "Just pissed off."

41. One of the users who stated that she had felt overwhelmed by the volume of information available thought an information pack for users covering the tribunal processes and legal issues might be useful, but with certain conditions:

SENDIST appellant: "As long as it was very focussed and this is what you do; step one, step two, step three and there was no variation in that. You know, you can do this or you can do that. It would have to be very streamlined, straight down the road process for everybody, the same. You know, not this, you can pay for a barrister. You don't have to have a barrister. You know, that's leaving the parent with choices and decisions. I think, keep it all the same, that all families, regardless of their ability to pay or not, got the same service ..."

Although none of the users interviewed had accessed the DEL Employment Rights series some users liked the idea of an 'information pack' covering a range of legal issues pertinent to their case. One I/FET claimant suggested it would be useful to have a "quick look" through the information, and another suggested that the main attraction was in having all of the information in one place. The latter point is one that other users have identified as desirable: to be able to go to one place where all the relevant information is available. 


\section{d. Vulnerabilities of users}

42. The users of the three tribunals in this study might be considered vulnerable due to the difficulties they are attempting to resolve at tribunal. Nonetheless, the vulnerabilities of users cannot be generalised and individual users may face a range of individual problems which make them particularly vulnerable. ${ }^{21}$ These vulnerabilities include mental and/or physical health problems and disabilities, and language problems:

Focus group participant: "probably $40 \%$ or more of [our social security] cases involve a degree of mental health illness ..."

Focus group participant: "it's the population that you're dealing with, and it's the complexity of the law that particularly applies to those people at that point in time, and you actually are dealing, for the most part, with people who have got quite a substantial amount of illness ..."

Focus group participant: "we see claimants who have difficulties ... just accessing these sorts of services around, you know, physical access issues, as far as disability is concerned, access issues for people with mental health issues, with learning difficulties and so on, people whose first language isn't English, people who have sensory deprivations ..."

43. Educational and social background also impact on the ability of users to access support and to take advantage of the support that is available, particularly in terms of understanding written information and advice:

Focus group participant 1: "do you think there's a socio economic slant to [the users who access online information]: the better educated? You get the people who won't be able to use ..."

Focus group participant 2: "Definitely, yes I do, I mean you do, you do have dealings with some people who are very well educated, intelligent people and know where to go to look for the information and do access it and do use it and will be formidable to deal with. You've got other people who just haven't a clue and don't know really, and maybe some people who ought to, who maybe don't know the information is there if they do want to look for it."

Focus group participant 3: "... the more educated and aware and IT literate you are, the more able you are to access self-help packs and to use them effectively."

Focus group participant: "The other aspect that needs to be looked at is also the ... educational attainment of the people who are coming to social security appeals. [I]t's not just a one size fits all ..."

\footnotetext{
${ }^{21}$ The findings on user vulnerabilities are supported by, for example, Alexy Buck and Liz Curran, "Delivery of advice to marginalised and vulnerable groups: the need for innovative approaches" (2009) Public Space: the Journal of Law and Social Justice 3(7): 1-29.
} 
44. Other vulnerabilities included users feeling overwhelmed by the prospect of appeal, intimidated by the process, and needing to prioritise other obligations at the expense of pursuing a tribunal case. Users identified themselves or others in their position as already having low emotional reserves, which also made it more difficult to process information and take action:

SENDIST appellant: "you're dealing with families that are already emotional. Because they're dealing with the kids' special needs. And sadly, they've had a big fight already, on their hands, to get children diagnosed and maybe get them into school and get them statemented. So I think families are already at a very low ebb."

SENDIST appellant: "other parents in my [autism support] group that were in the same position as myself and just, you know, wouldn't put themselves through going to tribunal. You know, so you have a lot of parents that, I suppose if the system was easier, would like to access it ... [T] hey didn't seem confident enough to go through that process.

Interviewer: "So it wasn't that they weren't aware of it, it was just that they didn't feel confident?

SENDIST appellant: "They were aware of it, I suppose, because I would have said and that was having me, even talking to them, tell them that I had been. But still, they just hadn't the wherewithal and maybe just family circumstances. They couldn't devote the time to. You know, so l'd say, I think you need to be a very... I would be a very strong and determined person. And you know, I think it takes that to go against the system and unfortunately, not everybody is like that."

Social security appellant: "I run back and forth to doctors, and I run back and forth to the ESA ... There isn't enough time, like, to try and get everything done."

45. In addition, where users found themselves under financial pressure - for example through the removal of benefits or wages - problems with progressing their case were exacerbated. Costs in bringing a case to a tribunal was also an area of vulnerability, with users identifying difficulties in meeting the costs of providing specialist evidence and accessing legal advice which was seen as necessary in order to 'match' the 'other side':

SENDIST appellant: "my Board said they took a barrister because we were taking a barrister. And I had the Board officer ring me and say, we're only taking a barrister because you are taking one. And I had to actually show that woman the letter where the ... Board had named a barrister before, to prove to her we were taking a barrister because they were." 
SENDIST appellant: "I heard families have spent thousands and thousands of pounds, going to tribunals. I think we spent $f 800$ on the psychology assessment ..."

Such costs served to make users feel more vulnerable and less able to pursue their case.

46. These vulnerabilities, combined or individually, may also create another category of vulnerable users, namely those who are hard to reach and for whom the barriers to providing pre-hearing support are significant. While this, and other, research has identified difficulties in assisting users who seek support, there is at least the prospect of improving the support that they seek. The difficulty presented by hard to reach users is that the traditional channels of providing support are ineffective. Users who have no access to online sources of help, users who are not represented by stakeholder groups, and are not part of networks or user groups may not have their needs represented; where needs are not identified it is difficult to meet them. This difficulty was recognised by the stakeholders in each of the three tribunals within this research.

\section{Section 3: Experience of support services}

47. Support for users is provided in three main ways: through written information, via tribunal staff and from advisers within the voluntary and statutory sectors. This research has already identified the barriers that users face in accessing written support, and the critical role that tribunal staff play in providing support for users who contact the tribunal. In addition, the research has identified the barriers for users in accessing advisers, and the desire expressed by users to be able to access support of this nature. The findings of this research echo those of the first Report that where users are able to access these organisations they find the information and advice to be very helpful:

SENDIST appellant: "I did go for some advice, I actually rang [the Children's Law Centre] up ... and then I went back and had an interview ... I found the interview really helpful."

I/FET claimant: "I found the advice from [CAB] very helpful. Very helpful."

What remains to be established are the particular ways in which this support is of value to users.

\section{a. Resolving problems at the earliest stage}

48. For users, the benefit of early advice was in helping them to avoid the dispute by making sure the initial decision was right from the outset:

Social security appellant: "that's one thing I would love to tell people out there, if you are going through [a benefit claim] ... go to the Citizens' Advice before ... you know, the whole way and keep them with you the whole way." 
Interviewer: "So even at that first bit where you're filling in a claim form, that's where you need help?"

Social security appellant: "Yes ... When the forms came out I just simply filled them all in, but at no stage did I realise that in actual fact you really do need ... somebody holding your hand and helping you out ... The Social Security Agency had the wherewithal to ... tell you ... where to go for help ... I don't know how you do it but I think ... it should be on the top of the form: 'get help to fill this in'."

Social security appellant: "the claim form I just did [myself]... that was my problem; I should have just went straight down to the Citizens Advice and they would have helped me make sure it was right; I think that was my drawback ..."

Social security appellant: "I'm sitting here with a Masters in English and I'm not reading those words [on the claim form]. I'm not reading that at all, and whenever it said 'do you need help?' ... my image of help was a person standing there to help me."

Interviewer: "But you think now [after the hearing] it's designed to get at some other concept?"

Social security appellant: "Yes."

49. Allied to the benefit of support in getting the decision right first time, users valued the support of advisers in helping them understand the initial decision that was under dispute. While this would most obviously relate to the first stage of the advice giving process set out above, it also applied to users being able to understand phrases that the tribunal would use. Without this advice, the language of relevant statutory provisions could remain incomprehensible, whether used by initial decision makers or tribunal members:

Social security appellant: " there were things that were said, and some of the phrases in [the hearing] went straight over my head ... And I'm not the stupidest person in the world ..."

An understanding of why the decision was made is critical in being able to successfully contest a decision the user disagrees with, since it enables the user to directly challenge the disputed issue in a focused way. Without this, users may simply miss the point of their case. While there is evidence that tribunal Chairs will try to help users understand what legal issues are under examination, ${ }^{22}$ Chairs are prevented from stepping beyond their duty of impartiality and assisting a party to the proceeding, so even the most user-friendly tribunal will not be able to compensate for the users' failure to address the justiciable issue.

\footnotetext{
${ }^{22}$ See for example Adler's research which revealed that tribunals have become much more enabling, due in large part to the increasingly active role played by tribunal Chairs. Notably, however, Adler's research points to a diminishing need for representation at tribunal where tribunal users have received pre-hearing advice: Michael Adler, The Potential and Limits of Self-Representation at Tribunals: Full Research Report ESRC End of Award Report, RE-000-23-0853 (2008).
} 
50. Users who did not receive early advice expressed frustration that the problems they encountered could have been resolved more quickly and more efficiently had they been better informed at the outset, which may have avoided the need to go to a tribunal hearing. This view is corroborated by a clear consensus from advisers and officials that advice should be given as early as possible - so that it is prioritised at stage one of the process set out above - and users should be made aware of the urgency in seeking advice at the earliest opportunity. From a departmental perspective, this was seen as advantageous in facilitating resolution at a local level, enabling good communication between the parties involved, protecting relationships (particularly in party vs party disputes) and delivering on customer service objectives to assist users. From the tribunal's perspective, this would mean that case loads could be reduced and the time spent at hearing could be more focused. From an adviser's perspective, the advantages of providing advice at an early stage are that it can prevent disputes becoming more complex, it can make users aware of the extent of their legal entitlements, and ensure that users are set on the correct path at the outset so that they pursue the most appropriate form of resolution for their dispute.

51. A number of participants within this research argued strongly that the failure to provide funding for advice at the early stage was a false economy:

Focus group participant: "not only do people have rights, but ... really there is some urgency in seeking advice as early as possible ... the earlier that you get advice, the better, the more options you have ... the more opportunity there is to resolve it informally and all those sorts of things. The absolute priority is to get in there as soon as possible ..."

Focus group participant: "In terms of resources, I think you can make the most ... difference with the least ... resources input, if you can give as much advice as possible at the earliest possible stage. I think that ... could have massive savings down the line ... Really what you have ... is a post holding Tribunal Chair being paid $£ 100,000$ a year ... taking twice as long to do the case as opposed to somebody providing the resources or advice, which might mean that we might not have got there in the first place, it could have settled or it could have resolved or could have withdrawn, and if it did run, I think if you reduce certain things, it's much easier to deal with, it will be quicker and it's much more likely to resolve."

Focus group participant: "you would find that if you're dealing with an unrepresented claimant, they don't always follow the directions from the Tribunal ... because they don't really understand them. You know, they will not understand, for example, what is a witness statement, and they don't understand about exchange of documents, what documents they're entitled to, what documents they're obliged to exchange ... and then, if something's not then done, if a direction isn't followed, it has a knock on effect because it has to knock out the whole timetable of directions ... I'm not saying that's 
always the case with unrepresented claimants, its not always the case, but very often it is ... and you run into problems ... [Y]ou've got to go back into the Tribunal again for another [case management discussion] and it increases cost ..."

52. Early advice on the merits of a user's case may not necessarily result in tribunal claims or appeals being withdrawn by users, given the variety of reasons users cite for bringing cases to tribunal, including wanting an independent adjudication of their grievance and their sense of being denied an entitlement that they are due. ${ }^{23}$ Some users may reject advice that their case is without merit and choose to progress to tribunal despite this, although it seems unlikely that all users would adopt this approach. Adler's research found that self-represented tribunal users who received pre-hearing advice were almost twice as likely as those who had not received pre-hearing advice to be successful at their tribunal hearing, suggesting either that 'better' cases or better prepared users were the ones who made it to hearing. ${ }^{24}$ Nevertheless, even where users are advised that their case lacks merit and decide to continue to a hearing, pre-hearing advice can provide useful information on tribunal processes as well as advice on the justiciable elements of the case. This may at least reduce the time spent by tribunals in having to address these issues with unrepresented and unassisted users.

53. In his response to the Ministry of Justice's consultation on the reform of Legal Aid in England and Wales, the President of the Social Entitlement Chamber of the First Tier Tribunal, HH Judge Robert Martin, also argues that "[e]arly intervention may avoid more expensive legal costs down the line.” 25 Where users do not understand the legal issues or tribunal procedures cases are more likely to be adjourned and hearing times extended:

"In welfare benefit cases, about $10 \%$ of the hearing time is consumed in explaining these basics. Compared to [assistance provided through Legal Aid], this is an expensive way of providing information, and rather late in the day." ${ }^{26}$

There is an intuitive logic to the cost-effectiveness argument - allied with the notion that prevention is normally better than cure - which is borne out in empirical research. For example, recent research by CAB demonstrates the savings that can be made per pound of legal aid spent where individuals receive early advice, and this report also provides a summary of other research on the

\footnotetext{
${ }^{23}$ See for example Redressing Users' Disadvantage, pp 28-29.

${ }^{24}$ Footnote 22, p 9.

${ }^{25}$ Ministry of Justice consultation: Proposals for the Reform of Legal Aid in England and Wales: Response by HH Judge Robert Martin, President of the Social Entitlement Chamber (February 2011), p8. Available at: www.judiciary.gov.uk/Resources/JCO/Documents/Consultations/legal-aid-responsefrom-sec-trib.pdf.

${ }^{26}$ Footnote 25, p7.
} 
cost-effectiveness of early advice. ${ }^{27}$ This is reinforced by evidence that problems beget problems, particularly for vulnerable individuals:

"the experience of problems has an additive effect - meaning that each time a person experiences a problem they become increasingly likely to experience additional problems." ${ }^{28}$

Where there is an opportunity to address problems at an early stage, the additive effect is reduced, and it would seem reasonable to assert that early advice provides a more cost-effective strategy than dealing with problems after they have developed and accumulated.

\section{b. External assessment of the case}

54. There were strong views expressed by advisers that early advice should include advice on the merits of the user's case, so that users could better judge whether the pursuit of their dispute was worthwhile or not. There was concern that failing to give this advice to users, for whom the personal, emotional or financial cost of pursuing a claim could be considerable, was a dereliction of an adviser's duty. This was set against the view that it was not (always) possible to make a call on the merits of a case from an initial consultation, and cases which initially seemed weak could turn out to be meritorious when further evidence was produced.

55. Although there was no consensus on when users could be advised of the merits or weaknesses of their case, there was consensus among advisers that they had a continuing duty to advise as to whether or not the user's case was likely to be successful. It was also the case that users valued an external, independent opinion on their case, and that this was so even where the external opinion was not supportive of an appeal, or where adviser opinions on the same case differed. In addition, users appreciated the honesty of advisers where harsh realities had to be faced:

Social security appellant: "[the adviser is] trying to get you to actually see your life as it really is."

Users saw this as helpful, allowing them to avoid pursing a case or a particular aspect of their case and more usefully focusing their efforts elsewhere.

\section{c. Awareness of tribunal rules and procedures}

56. Each tribunal operates under rules and procedures specific to it, and these rules and procedures are not common knowledge for most people. These involve issues

\footnotetext{
${ }^{27}$ CAB, Towards a Business Case for Legal Aid, July 2010, London: CAB. The logic of prevention being cheaper than cure is also addressed by the House of Commons Health Committee in relation to resolution of complaints within the NHS. The Committee finds that "there may well be a business case for further support for [the Independent Complaints Advocacy Service] in order to reduce the number of premature complaints received by the Ombudsman." Complaints and Litigation: Sixth Report of Session 2010-12, 2011, HC786-1, para. 71.

${ }^{28}$ Pascoe Pleasance, Alexy Buck, Nigel Balmer, Aoife O'Grady, Hazel Genn and Marisol Smith, Cause of Action: Civil Law and Social Justice, (2004) London: Legal Services Commission, p7.
} 
such as the time limits for lodging cases and the submission of late evidence, which can generate difficulties for the unwary user. Procedural rules on accepting late evidence for SENDIST hearings were identified in Redressing Users' Disadvantage as being problematic for users; this is corroborated by contributors to this report. Time limits for lodging appeals has also emerged as an issue. Advisers and tribunal staff were clear that there was a need for users to be informed at an early stage about the tribunal rules and procedures to enable cases to proceed to hearing:

Focus group participant: "it's not enough that people know what their rights are, but there needs to be information about timeliness ..."

Focus group participant: "you ... try to avoid court action at all costs ... If ... that doesn't work and those steps don't bear out, it's, how do you lodge proceedings, when, what forms do you use: procedural type issues ..."

Focus group participant: "we see [users] coming in to us who may well have had perfectly feasible cases and their time limits have just gone by ..."

One user who had missed the deadline for submitting his case was of the view that time limits should be extended, and that his failure to submit on time should not prevent the tribunal adjudicating on what could otherwise be a meritorious case. While clearly tribunal procedural rules have to establish limits for the submission of cases - and this research does not examine the appropriateness or otherwise of existing time limits - where users are not sufficiently aware of these rules and procedures they will, equally clearly, have problems in accessing justice.

57. As Redressing Users' Disadvantage identified, the lack of familiarity with tribunal procedures meant that users find the prospect of the hearing very daunting. This finding is corroborated in the current research:

Social security appellant: "I was [at the tribunal] before as a representative for somebody but I still didn't know exactly what to expect ... And I think forewarned is forearmed ... I came in very agitated because I didn't know what to expect ... I think had I been calmer it would have been easier"

SENDIST appellant: "the only thing that panicked me [was that] I didn't know how things were going to happen. I think it would have been best to be told, this is what will happen. There'll be a room, the Chairperson will say, will do this. He will ask the Board questions. You will be allowed to step in. There was none of... I would have liked all that, to know how it's going to go. Yes, they say it's meant to be very informal and not intimidating. But it is intimidating if you don't know how things are going to go. And I only knew that the Board would have ... been allowed to speak first ..." 
58. Where users did not have access to pre-hearing advice, they identified the management of their expectations of the hearing as an area in which they would like to have had support:

Social security appellant: "Just to know what you're going to be in for."

Social security appellant: "Just to make it not as daunting ... You wind yourself up thinking it's going to be this, and that, and the other ... and it's just to tell you it's a bit more of a softer approach ..."

For these users, a run-through of the format of the tribunal and, in particular, the types of questions they were likely to be asked was seen as being as important as legal advice on their case. This knowledge gap was also identified by representatives in relation to witnesses. It was argued that the witness statement could provide a means of preparing witnesses on what they could expect from the tribunal, although research participants were not uniformly in favour of witness statements.

\section{d. Equality of arms}

59. Closely linked to users' desire to understand better what a tribunal hearing involves is the intimidation users feel at having to face a more knowledgeable 'opponent' who is familiar with the tribunal processes and the law governing the dispute in a way that the user is not. This applied equally to inquisitorial tribunals (where the 'opponent' was the relevant Department) as it did to adversarial, party vs party tribunals where the 'other' party was legally represented. For many users, the need for an equality of arms between parties was pressing:

SENDIST appellant: "it was new territory to us. We had no experience of it and it was just, to be honest, the fact that you were going somewhere where you knew you were going to come up against people who had experience of it. And this was their job. The ... Board have been to tribunals before, so you felt very, very one-sided, very inadequate from that regard. You know, you just felt really, you were coming up against a well-oiled machine."

SENDIST appellant: "I know what the court system is like ... I've been familiar with it, only because of the divorce situation ... But when you've gone through something like that, you don't particularly want to put yourself in that position again ... even doing the tribunal thing was quite similar. I'm not saying it was the same; it was by far, better. But, at the same time, you are aware that it is a legal process and you are aware, you know, that you are representing yourself and you are representing your [child] and that, sort of, all comes down to you. And just, sort of, that, sort of burden of responsibility, kind of thing. So you are aware of it."

Access to advice and representation gave users reassurance that they were better able to "protect" their case; where users had access only to pre-hearing advice they appreciated this as useful preparation for their hearing but nevertheless still voiced a desire to have someone at the hearing to speak for them. In addition, this 
equality of arms was identified by advisers and departmental and tribunal staff as overcoming users' naivety in not being able to identify the legal issues at stake and the evidential requirements needed to support them.

\section{e. Facilitating an alternative resolution}

60. Good advice does not always involve advising users to go to tribunal. The value of advice also comes through raising awareness of the stages at which disputes may be considered prior to a tribunal hearing or of the alternatives that may be available to help users resolve their dispute. This research has found that there were mixed views among users about alternative processes to resolve their disputes.

61. There was evidence in this study, as in the previous study, that SENDIST users have an ambiguous attitude towards the Dispute Avoidance and Resolution Service (DARS) that is set up to mediate disputes between parents and Education Boards. On the one hand, parents insist they would have done anything to have avoided a tribunal hearing, but none chose to use DARS, with some positively rejecting the idea:

SENDIST appellant: "[Had an ADR process been in place] I would have used it the first time [I took a case to tribunal], because I would have tried anything the first time. The second time, I wouldn't use it, because I had no faith in them and it was a waste of my time..."

A lack of faith in the independence of DARS is compounded by parents not understanding how DARS could negotiate something the appellant had previously been unsuccessful in negotiating. ${ }^{29}$ This was exacerbated by appellants' belief in intransigence on the part of the Board, connected to what they perceived as a strategic decision by the Board to push the appellant to the door of the tribunal in the hope that the case may not proceed:

SENDIST appellant: "our barrister was floating between us and the Education Board. And I felt they had made the decision before they went there, what they were going to give us. And they just took us there to put us through that. Because there was no argument. Basically, we had it settled in five minutes."

62. Advisers have a key role to play in negotiating with 'the other side' to resolve the dispute prior to a hearing. They can significantly enhance the chances of having pre-hearing negotiation, either by recommending processes like DARS to users, or

\footnotetext{
${ }^{29}$ The confusion by appellants about the role of DARS is mirrored in the research on Dispute Resolution and Avoidance in Education which found that, among the various factors affecting the use of mediation for special educational needs disputes in England, and Additional Support Needs disputes in Scotland, were that parents do not understand mediation, doubt the mediator's independence and their negative experience of dealing with the education authority deters them from engaging with mediation: "Dispute Resolution and Avoidance in Education: Briefing Paper", Neville Harris, Sheila Riddell, Emily Smith, Joan Stead, Elisabet Weedon and Kevin Wright, October 2009, Dissemination conference, University of Manchester.
} 
in directly approaching 'the other side' to negotiate a settlement. In relation to employment claims, there are views across the spectrum on the issues raised by respondents negotiating with unrepresented users. Views range from respondents, or their advisers, feeling inhibited in approaching unrepresented users to those who were seen to take advantage of the user's lack of representation by offering minimal settlements and threatening costs against the user. At both ends of the spectrum, there is value in having an adviser who can facilitate a fair process of negotiation with respondents or public bodies, and potentially avoid a tribunal hearing.

63. In relation to social security disputes, the DSD official was clear that the policy of the Department was to encourage resolution of disputes prior to the tribunal hearing, and to encourage users who had additional information to contact the Department at any stage prior to their hearing to see if the decision could be reconsidered. While this may be part of the formal reconsideration process, the DSD was also clear that "the law allows us to change a decision right up to the day of the hearing”, and so further information from users would be considered at any stage "to prevent unnecessary appeals". User representatives saw this as a very helpful provision, and often utilised it on behalf of clients. The difficulty that representatives identified, however, is that departmental staff may not always be willing to review decisions outside formal reconsideration processes. This appeared to be particularly so closer to the date of the hearing, especially where the claimant's case had been referred to the departmental appeal writers, or on to The Appeals Service. In such cases, the preferred position was to leave the reconsideration of the decision to the tribunal. Representatives sought to remedy this by fostering good relationships with departmental staff to improve the prospects of reviewing a case prior to appeal. While this could be achieved more easily with staff at local offices, it was regarded as more difficult to build relations with staff in central offices. In both cases, efforts in building relationships were reliant on the same staff staying in the same roles.

\section{f. Personal contact}

64. Users regarded personal contact with advisers and support workers as very important. Even where users had access to good written information that they could follow, they still appreciated being able to talk to an individual who had an understanding of the processes and the area of law involved. Where users did not have access to, or did not understand, written information on these issues, the value of personal contact was increased:

Social security appellant: "between me being ill and coming to this level it was all paperwork ... there was no real person involved."

Social security appellant: "It would be nice to have an advice line ... That kind of thing, if you've got any questions to ask ... Somebody that knows something about these cases and you know, somebody that can give you a wee bit of support." 
Unrepresented users of I/FETs identified the LRA as a useful resource in this regard, finding it helpful to be able to pick up the phone and get advice on things such as writing letters, "because it told me what to do and ... what I could expect and all that." It is also clear that users access tribunal staff for this purpose on the basis that they much prefer to get the information in person, and appear to be better able to understand the information that is given via personal contact. The difficulty (as discussed above) is where the user seeks advice beyond the limits of information that tribunal staff are able to provide. 


\section{CONCLUSIONS AND RECOMMENDATIONS}

65. Redressing Users' Disadvantage identified a similarity of experience between the users of the Northern Ireland tribunals within that research and the experiences found by Sir Andrew Leggatt to have existed for users of UK-wide tribunals ten years ago. ${ }^{30}$ The purpose of this report is to develop that knowledge further by identifying the nature of the issues faced by Northern Ireland users pre-tribunal, and it is clear that the findings of this report also map on to the issues highlighted by Leggatt. Leggatt's objective was to determine how the tribunal landscape for UK-wide tribunals - not including those tribunals within the competence of the devolved institutions in Northern Ireland, Scotland and Wales - could be improved. His central recommendation was to adopt a user-focus for tribunal reform by removing tribunals from their sponsoring departments and by keeping the system of tribunals and administrative justice under review by the Council on Tribunals. Leggatt's concern for users was that too often they did not understand the initial decision they were seeking to challenge, or whether there was a justiciable basis for that challenge; that they were daunted by the tribunal hearing, and did not know what was expected of them at the hearing; that users required support to decide if they should progress their dispute to a tribunal hearing; and that, for self-representation to be feasible, users should have access to an adequate system for the provision of information and advice. This report corroborates that these concerns remain for Northern Ireland users. The first recommendation of Redressing Users' Disadvantage must therefore be reiterated:

\section{Recommendation 1 (a)}

Users must be the focus of the Department of Justice and its policy and executive units in relation to tribunals and administrative justice.

As Redressing Users' Disadvantage identified, there was a timetable for transferring the administration of the different Northern Ireland tribunals to the NICTS, with the third phase of transfer to take place in April 2011. That third phase transfer has not yet taken place, and so I/FETs along with Planning/Water Appeal Commissions and the Police Medical Pensions Appeal Tribunal, remain within the administrative control of their sponsoring Departments. In order to avoid disadvantaging these tribunal users, the first recommendation of Redressing Users' Disadvantage requires an addendum:

\section{Recommendation 1 (b)}

Where tribunals are not administered by the Department of Justice, tribunal users must be the focus of their sponsoring departments.

66. In ensuring that Department of Justice policy could provide a user focus, Redressing Users' Disadvantage looked not just at actions that had to be taken but at processes that needed to be implemented for the actions to be effective. In particular, the report recommended the structured, holistic response to resolving disputes encapsulated in the concept of Proportionate Dispute Resolution:

${ }^{30}$ Sir A. Leggatt, Tribunals for Users: One System, One Service, (London: TSO, 2001), para.11.3. 
- minimise the risk of people experiencing legal problems by ensuring that the framework of law defining people's rights and responsibilities is as fair, simple and clear as possible, and that State agencies, administering systems like tax and benefits, make better decisions and give clearer explanations;

- improve people's understanding of their rights and responsibilities, and the information available to them about what they can do and where they can go for help when problems do arise. This will help people decide how to deal with the problem themselves if they can, and ensure they get the advice and other services they need if they cannot;

- ensure that people have ready access to early and appropriate advice and assistance when they need it, so that problems can be solved and potential disputes nipped in the bud long before they escalate into formal legal proceedings;

- promote the development of a range of tailored dispute resolution services, so that different types of dispute can be resolved fairly, quickly, efficiently and effectively, without recourse to the expense and formality of courts and tribunals where this is not necessary; but also

- deliver cost-effective court and tribunal services, that are better targeted on those cases where a hearing is the best option for resolving the dispute or enforcing the outcome. ${ }^{31}$

These processes encapsulate the majority of the issues identified in this research, and the recommendations of this report can be mapped on to these stages of proportionate dispute resolution. It is clear from the findings of this research that users need and value support in order to understand their basic legal entitlements and the legal issues raised by their case, and to follow through the necessary processes where they wish to contest the initial decision.

\section{Initial decision making}

67. Support for users must begin with the initial decision makers. Users need more support to understand the decision that has been reached, to understand what further or new information might assist them in challenging that decision, and to make them aware of how to challenge a decision, through informal and formal methods of resolving disputes prior to the tribunal. It is clear that Departmental processes have been created to ensure that decisions can be reviewed at various stages prior to the tribunal hearing, but this does not always translate into workable arrangements between users and decision makers. This research has identified some issues that suggest a change of culture or additional education of

\footnotetext{
${ }^{31}$ Transforming Public Service: Complaints, Redress and Tribunals (London: HMSO, 2004) Cm 6243, para. 2.3. In addition, it is worth considering that, in the most significant pieces of work done on principles of good administration, the consistent features are the duty to get decisions right first time, to explain decisions to users so they can understand them, to quickly put right decisions that are wrong and to provide assistance to users throughout the administrative process. See most recently AJTC, Principles for Administrative Justice, 2010. This is also reinforced by the Access to Justice Review Northern Ireland Report which endorses a 'systems thinking' approach to administrative justice: para. 5.133.
} 
staff may be required within pockets of relevant Departments to ensure that users are enabled to resolve disputes in the way that Departmental policy intends.

68. Recent research published by Advice NI, which shows the impact of the problem of failures at first instance decision making, also reinforces the need to improve the quality of initial decision making. ${ }^{32}$ Advice NI's report, The Big Idea: Putting People First, was based on research published by Advice UK which used a 'systems thinking' approach to studying demand and redesigning service delivery to meet it. ${ }^{33}$ Using this approach, the service an organisation provides is looked at holistically to identify patterns and cycles in systems, rather than seeing only specific events in the system. The Advice UK report identified that the majority of the workload of advice agencies in the pilot areas in England and Wales was caused by the failings of the Department for Work and Pensions, HM Revenue and Customs and Housing Benefit Offices to deal with customers correctly from the outset. ${ }^{34}$ Advice NI's research builds on this, although due to delays in agreeing levels of engagement with key statutory stakeholders and because of time constraints the project was only able to complete three of the six stages of the systems thinking methodology to 'check' the system, and so further research is required. ${ }^{35}$ What is revealed by the research at this stage is that, in the pilot areas in Northern Ireland, social security and housing problems accounted for the majority of queries being directed to Advice NI. The research concludes that enquiries directed to Advice NI were predominantly connected to the failure of the Social Security Agency (SSA) or the Northern Ireland Housing Executive (NIHE) to "do something or do something right for the customer":

"Demand analysis of these enquiries highlighted that $80 \%$ were categorised as 'failure' demand: work that should not need doing, caused by failings 'further back' in the systems of the SSA and NIHE; It was found that $20 \%$ of enquires were categorised as 'value' work (for example the client wanted to know if they might be entitled to help);" ${ }^{36}$

Within a systems thinking model, 'failure demands' are demands that organisations do not want, whereas 'value demands' are those demands organisations want users to place on them, since they are the reason why the organisation exists. The argument is therefore that if 'failure demands' can be removed at source by the relevant Department, advice organisations can better direct their resources to responding to 'value demands'.

\footnotetext{
${ }^{32}$ Advice NI, The Big Idea: Putting People First (2011), available at: www.thesystemsthinkingreview.co.uk/index.php?pg=18\&utwkstoryid=318

${ }^{33}$ Advice UK, It's the System, Stupid! Radically Rethinking Advice (2008), available at: www.adviceuk.org.uk/projects-and-resources/projects/radical/ITSS

${ }^{34}$ Evidence of poor quality initial decision making by government departments in England and Wales, including the Department for Work and Pensions (DWP) is also provided in the AJTC report Right First Time, which also reviews the steps taken by the DWP to improve initial decision making. See AJTC, Right First Time (2011) London: The Stationery Office, available at: www.justice.gov.uk/ajtc/docs/AJTC Right first time web(7).pdf.

${ }^{35}$ Footnote 32, p 23.

${ }^{36}$ Footnote 23, p7.
} 
69. It is clear that where an organisation faces challenges in discharging its obligations - which, in systems thinking terms, could be seen as resulting in 'failure demands' being placed on advice organisations - then steps taken to address these challenges will inevitably positively impact on users and on the nature of demands placed on other organisations that support users. While it does not accept the findings of the Advice NI report, nevertheless the SSA recognises that challenges in assisting its customers still remain. In particular, DSD staff identified the difficulty in getting users to assist decision makers by providing as much information as possible in relation to their claims for benefits, a difficulty that arises through user ignorance but that may also be partially attributed to a lack of trust users may have in decision makers, particularly where an earlier benefit claim has been rejected. There is a circularity to the problem of improving first instance decision making: users do not trust decision makers within the SSA, and do not wish to engage with them beyond the minimum amount necessary. ${ }^{37}$ The result can be that users do not provide decision makers with full information and evidence to support their claim even when the necessity of doing so is made clear to them, preferring instead to have the issue adjudicated by a more independent body, namely the tribunal. Added to this, many users do not know that they need to provide particular types of evidence to substantiate their claims, and where this becomes apparent to users prior to a hearing, decision makers may prefer not to deal with it and defer the issue to the tribunal for resolution, further reinforcing any negative views the user may have about the departmental attitude to their claim.

70. This research was not focused on establishing the quality of first instance decision making within any of the Departments, and does not make a finding as to the quality that exists. Nevertheless the research does find that users struggle to understand what information first instance decision makers require, and to understand why the decision was made. Users who do not understand what is required to make out a successful initial claim will struggle to construct a valid case through all stages of a dispute resolution process.

71. Departmental staff are alive to the difficulties faced by users in struggling to understand why initial decisions have been reached, and to the operational challenges inherent in achieving an ideal solution. DSD staff identified ongoing developments to try and address these issues, including: developing inter-agency approaches so that a start-to-end process of resolving disputes can be implemented; considering issues that impact on users across the different agencies they deal with; and considering additional means of educating users about their rights and responsibilities. This is reinforced by the Access to Justice Review Northern Ireland Report, published in September 2011, which recommends that the Department of Justice should be a member of the DSD led Government Advice and Information Group and that the group could examine additional ways to support users. A specific means of addressing this, such as the idea of providing a two-page summary of the Appeal Submission (to be provided in addition to the

\footnotetext{
${ }^{37}$ See for example A. Irvine, J. Davidson and R. Sainsbury Reporting Changes in Circumstances: Tackling Error in the Benefit System (2008) DWP Research Report No. 497, London: TSO; H. Dean and M. Melrose “Unravelling Citizenship" (1996) 48 Critical Social Policy 3: 11.
} 
full Submission) was also well received by DSD staff and tribunal judiciary. Given the difficulties highlighted by Appeal Tribunal users in understanding the Appeal Submission, there is a critical need to address this issue within a joined-up approach. The AJTC has recently produced a report which identifies systematic ways to improve initial decision making that could usefully inform a crossdepartmental analysis in Northern Ireland on how to get decisions right first time. ${ }^{38}$ The importance of first instance decision making must therefore be acknowledged as a means of supporting users:

\section{Recommendation 2}

Improve first instance decision making, ensuring that staff implement Departmental policy to resolve disputes at an early stage. This includes making sure users understand what information they are required to provide to decision makers and that they understand the reasons for the decision that has been made.

\section{Written information}

72. Ensuring users are better informed about first instance decision making also overlaps with the second stage of proportionate dispute resolution which requires users to have an improved understanding of their rights and obligations, and improved information on what they can do when they disagree with a decision and where they can go for help. These are critical issues for this research, which has found that users are not knowledgeable about their rights and how to enforce them, or how to get support to help them to raise or respond to a dispute. While a number of different forms of assistance and support have been devised to help users through the process of challenging a decision, not all of these are successful.

73. In particular, this research has established that written information for users is not a panacea. There are some examples of extremely competent users for whom the existing information on their rights was sufficient, either because their cases were relatively straightforward, or because they had the ability to understand and apply complex information. Unfortunately, too many users do not fit these profiles and for these users understanding written information is fraught with difficulties. Users tend not to read or properly process the information, and are unable to access it because of personal vulnerabilities which make the general issues of complexity and volume of information much more difficult to overcome. Users want information that is clear, concise and understandable, that takes account of low levels of knowledge, and that provides simple directions which they can follow.

74. While there are some very good examples of where complex legal information has been reduced to a more comprehensible format, ${ }^{39}$ the difficulty is that the goals of simplicity, brevity and accessibility may come at the expense of the primary purpose of the law that is being conveyed, namely the clear expression of what Parliament or the judiciary intends. Examples of this were provided within this research, where users relied on information booklets as primary sources of legal information, not understanding that the information booklets could not be

\footnotetext{
${ }^{38}$ Footnote 34.

${ }^{39}$ For example the Employment Rights guides published by DEL.
} 
representative of all of the nuances of the legal position, despite specific warnings advising them of this. It is also notable that even where users were able to understand written information they still appreciated the opportunity to clarify their understanding with relevant individuals within support organisations.

75. Again, departmental and tribunal staff are not complacent about the efficacy of written information, but are aware of its role in supporting users and continue to look for best practice. In order to achieve this, staff compare information from equivalent tribunals in Britain - particularly where information goes through a 'Plain English' vetting process - and utilise it where appropriate. They also build on links with different agencies and organisations to develop an agreed body of information which is representative of a range of stakeholder perspectives and may therefore have more credibility with tribunal users. It would also seem prudent to road test this information with users to more accurately establish its accessibility, particularly in relation to users with disabilities or special needs. Models of self-help materials that could be considered include those provided by the Independent Complaints Advocacy Service (ICAS) that operates in England for users who have complaints about any aspect of their NHS treatment. ${ }^{40}$

76. Some good written information is already available but users are not always aware of this information or how to access it. Users identified a need for this information to be easily available to them, and for all of the necessary information to be available from one place to avoid users having to trawl through different sources or missing out on aspects of information that might be useful. It is not clear where this 'one place' should be; no consensus was revealed by users as to where they might intuitively look for this information. In many ways it could be that the tribunal is the most obvious place to locate this information, but two difficulties arise. First, tribunals may not see their function as being the portal to information on legal issues. Second, users may need this information in order to access the tribunal, and, conversely, to avoid having to go to the tribunal. Providing the information via the relevant Departments would also appear to be sensible, but it is unlikely that all users will access information this way.

77. Users within this study identified a range of channels that they utilised, which varied from support groups dealing with medical issues to government information channels such as NI-Direct. If information is sourced from and agreed by a range of stakeholders this may help to identify and provide multiple sites for relevant information. As a minimum, information should be available from relevant Departments and their agencies, including the Department of Justice and the NICTS, from tribunals, from voluntary and community sector organisations that currently assist users, and further work should be done with users to identify where they would most like to access information from. The information should be available in hard copy as well as online.

\footnotetext{
${ }^{40}$ Three organisations are franchised to provide this service: SEAP, POhWER, and Carers Federation Limited. See, respectively, www.seap.org.uk/icas/, www.pohwer.net/how we can help/independent.html and www.carersfederation.co.uk/what-we-do/icas/.
} 


\section{Recommendation 3}

Improve written information for users to advise them of their rights and obligations, and options for dispute resolution. This could include further evaluation of good practice in this area such as the easy-read guide produced by the Tribunals Service; utilising Plain English processes; providing one/two page summaries of appeal submissions, in addition to the submission; and working with a full range of stakeholders who provide support to users.

\section{Recommendation 4}

Develop effective methods of obtaining feedback from users on the efficacy of the information.

\section{Recommendation 5}

Identify, in consultation with users and relevant stakeholders, including departmental and voluntary sector bodies, the ways in which users could best access written information.

\section{Video information}

78. Written information remains a necessary tool to assist users, but it is clear that this form of support has its limitations and more innovative approaches to providing information and support to users need to be considered. One acknowledged method of providing information about the tribunal was through video information demonstrating what to expect at a tribunal and advising users on the roles of tribunal members and staff, how to prepare the case, the role of evidence in the hearing and how the hearing is likely to proceed. This form of information would be particularly useful for tribunals which do not hold public hearings and where users are not able to, or not aware of being able to, attend hearings in advance of their own.

79. HM Courts and Tribunals Service (previously the Tribunals Service) provides a DVD and online 'you-tube' clips of this type of information for the SEN Tribunal in England, ${ }^{41}$ which was commended by Leggatt in his report. ${ }^{42}$ While this information is clearly specific to England, it could nevertheless be of value to Northern Ireland users, in lieu of a Northern Ireland version of the information. Other notable examples of video information include the Victorian Civil and Administrative Tribunal in Australia which provides users with online video guides on the issues involved in taking and presenting a case at tribunal, including a video guide to mediation. ${ }^{43}$ The Additional Support Needs Tribunals in Scotland also have a ten minute DVD on their website which gives a brief introduction to the Tribunal, based around a 'Frequently Asked Questions' format,

41 Available from the Justice website at: www.justice.gov.uk/guidance/courts-andtribunals/tribunals/send/appeals/video-guide.htm

${ }^{42}$ Footnote 30, para. 4.2.

${ }^{43}$ Available from the Victorian Civil and Administrative Tribunal website at: www.vcat.vic.gov.au/CA256DBB0022825D/page/Video+guides?OpenDocument\&1=12Video+guides $\& 2=\sim \& 3=\sim$. 
rather than a step by step guide to tribunal procedures. ${ }^{44}$ While this may not be as useful for users as seeing a simulated tribunal hearing, it might nevertheless provide some advantages over written information. Given that Northern Ireland users identify the prospect of the tribunal hearing as intimidating, video information could prove to be very useful in allaying fears and providing some reassurance and support.

80. Departmental and tribunal staff recognise this, but have identified cost as a barrier to implementing this idea, although NICTS is currently considering providing a link to the SEN Tribunal video, and the idea of video information for other tribunal users is supported by tribunal judiciary. Other obstacles to providing video information that were recognised included the difficulty in being able to provide a 'typical' tribunal hearing. The importance of identifying what might constitute a 'typical' hearing should perhaps not be overstated. Where users, for example, attend an Industrial Tribunal hearing in advance of their own case, there is no guarantee that what they witness is a typical hearing, yet it is also clear that they still value the experience as useful preparation for their own hearing. Modelling particular tribunal cases could also usefully draw on Genn and Thomas's forthcoming research which uses simulated tribunal hearings to explore how tribunals make decisions. ${ }^{45}$ While the issue of costs remains a live one - and clearly the costs of such a development would need to be understood and justified - it may still be worth considering whether, for example, partnerships with University projects might provide a less expensive means of producing video information. In addition, the Scottish format of videoing basic questions and answers might be relatively easy to replicate, and could address difficulties that users face with written information in particular. It would also be useful to monitor the nature of queries to tribunal staff to establish, inter alia, the volume of queries which are concerned with questions that video information might usefully answer.

\section{Recommendation 6}

Departments with responsibility for tribunals should continue to explore the potential of providing video information for users on dispute resolution processes and what these processes require of users.

\section{Recommendation 7}

Tribunal Secretaries should document the nature of calls to tribunal staff to establish what users most request assistance with and whether patterns of need vary.

\section{Early advice consultations}

81. It is clear from the research conducted for this report, as for the last, that users value support in disputing a decision they disagree with. In particular, users appreciate the ability to talk to someone about their case or about the process

\footnotetext{
${ }^{44}$ Available from the Additional Support Needs Tribunals for Scotland website at: www.asntscotland.gov.uk/asnts/353.225.225.html

${ }^{45}$ Hazel Genn and Cheryl Thomas, Tribunal Decision Making (forthcoming), funded by the Nuffield Foundation. See: www.nuffieldfoundation.org/tribunal-decision-making.
} 
involved in bringing, or responding to, a case at tribunal. Reinforcing Leggatt's view that users require support to decide how to progress their dispute, this research finds that support is often not just desirable but necessary to allow the user the opportunity to ask and have answered the question 'what is the legal issue?' Lawyers and specialist advisers are trained to think in this way, and the legal process that governs most dispute resolution procedures poses this question, but users are not, on the whole, equipped to ask or answer this question. Different forms of assistance and support continue - rightly - to be developed as a means of supporting users through the process of challenging a decision, but it must be recognised that not all of these forms of support will be successful for all users. For many, individual and personal contact with an adviser remains the best support option.

82. While face to face advice emerges as the optimum form of support, there are obvious limitations to building recommendations around this, in particular the issue of cost which is likely to be the primary objection to the idea of expanding personal support to users. What is not clear, however, is whether the cost of providing additional resources for advice is any greater than the costs that result from users proceeding with cases without advice. One of the strongest and most important findings to emerge from the research was the need to prioritise early advice, the benefits of which were seen to manifest themselves in a number of ways. Users are given a clear sense of whether their grievance amounts to a justiciable claim and what issues their case needs to address. They can be advised at the outset how best to pursue their case, thus avoiding the difficulty highlighted for I/FET users in particular of setting off on the wrong path and ultimately losing their right to lodge the correct claim. In addition, where users can address the justiciable issues in a procedurally correct way, either in oral evidence and/or through the provision of relevant information which addresses an evidential gap in their case, tribunals will be able to deal more efficiently with their case, with a potential saving in time and resources. This also corresponds with Leggatt's view that for users to be able to represent themselves at tribunal they should have access to pre-hearing information and advice, although - as Redressing Users' Disadvantage identified and the Access to Justice Review Northern Ireland Report recognises - the need for representation for many users is likely to be a continuing one. ${ }^{46}$ Pre-hearing advice is not a substitute for representation and should be considered alongside the issue of availability of representation.

83. The argument that early advice is cost-effective was raised by contributors to this research, reinforcing arguments put forward by the President of the Social Entitlement Chamber of the First Tier Tribunal and empirical evidence such as that provided by CAB. ${ }^{47}$ It remains to be fully explored how cost-effective early

\footnotetext{
${ }^{46}$ See pp33-37, and recommendation 3. See also Adler and Gulland, footnote 14, particularly para. 3.3; Hazel Genn, Ben Lever, Lauren Gray with Nigel Balmer and National Centre for Social Research, Tribunals for Diverse Users, (DCA Research Series 1/06, 2006) available at: www.dca.gov.uk/research/2006/01 2006.pdf. Recent research by Adler suggests that the 'representation premium' may have reduced, most notably in cases where users have advice and support prior to their hearing, but it should also be noted that the research does not conclude that representation is no longer necessary: footnote 22 .

${ }^{47}$ See footnotes 25 and 27.
} 
advice would be for tribunal users in Northern Ireland but it would be unwise to dismiss the argument entirely, particularly if the primary recommendation of Redressing Users' Disadvantage is to be implemented, namely making users the focus of Department of Justice policy on tribunals and administrative justice. This research has established that most users will require personal support for a range of issues, whether to clarify information that has been received, to direct them to the most appropriate form of resolution, to enable them to understand and assert their rights, or to take them through complex legal issues and processes at a time when they are most vulnerable. Some of this support can be and is very ably provided by tribunal staff, but there is a clear gap beyond this between what users need and what support exists.

84. The Access to Justice Review Northern Ireland Report raises the case for "publicly funded advice and assistance on legal issues arising from benefits, debt, housing and education to be provided to financially eligible people by expert suppliers through contracts or grants administered by the Legal Services Commission." 48 This recognises and prioritises the need for early advice, and underlines the need for support to be accessible, in geographical terms and in relation to forms of communication that could be used. Recommendation 43 of the Report therefore proposes "that advice and assistance in case preparation for, and where appropriate help at, tribunals should be included in the consideration of the mixed model for advice and assistance." 49 The Report also endorses the models of specialist advice to supplement provision by generalist advisers for issues like immigration, social security and housing where general advisers can refer complex cases to specialist organisations like Law Centre (NI) or Housing Rights Service, so that users may receive the best advice possible.

\section{Recommendation 8}

The Department of Justice should conduct research on the cost-effectiveness of providing tribunal users with an initial personal advice session at the outset of their dispute, with advisers who are equipped to advise on the specialist issues dealt with by tribunals and to identify other justiciable problems the user may be experiencing. Funding for this research should come from government Departments with policy responsibility for tribunals and for the issues dealt with by tribunals.

\section{Recommendation 9}

This research could usefully include a pilot of pre-hearing support sessions for users of one of the smaller tribunals, using the pilot to evaluate the specific benefits of pre-hearing support.

\section{Facilitating referrals for users}

85. The strategy of addressing problems at an early stage is also likely to have a positive impact for users on what is known as the additive effect, whereby the justiciable problems of vulnerable users are more likely to generate additional

\footnotetext{
${ }^{48}$ Footnote 16, para. 5.32, recommendation 52.

${ }^{49}$ Footnote 16, para. 5.15 and recommendation 43.
} 
problems, including justiciable social and economic problems. ${ }^{50}$ Consideration should also be given, therefore, to strategies which can address all of a user's problems:

"Earlier studies have stressed the benefit of 'a degree of co-ordinated management' in the delivery of related legal services. For example, as well as the benefit of greater proactivity and timeliness in the identification of related problems by professionals, there is also the benefit of averting the 'referral fatigue' that sees a greater likelihood of people giving up their search for advice each time they are directed from one adviser to another." ${ }^{51}$

The issue of referral fatigue is critical given the barriers users face in accessing information, advice and support. If users are to access support, then those they deal with need to be properly equipped to identify and address their problems, and there needs to be effective co-operation between the organisations that can help to resolve user problems.

86. The ideal solution might be for a one-stop shop for users where they could access support across a range of problems from health to housing to finance. However, support organisations in Northern Ireland are not equipped to function in this way and will need to continue to rely on other organisations to take on referrals. Consequently, effective co-ordination between existing support organisations is required to ensure that users do not suffer referral fatigue and can have each of their problems dealt with in an efficient manner. The objective here is to ensure that users are not pushed from pillar to post but are given the assistance they need at the earliest opportunity. There is also an implicit requirement here to ensure that there is adequate capacity within referral organisations to take on the referrals. The Access to Justice Review Northern Ireland Report also emphasises the need for partnership working, to address clusters of problems that users may have, and to familiarise advisers with support that is available, and it recommends that relevant government departments work together to progress this objective. ${ }^{52}$

\section{Recommendation 10}

Related departmental, statutory and voluntary sector services that deal with users should work collaboratively to ensure that referrals to and from their organisations are dealt with efficiently and effectively. The Department of Justice should work with these organisations to identify where the gaps are in dealing with referrals, so that resources may be allocated in the most focused way.

\section{Innovation in the provision of support}

87. The difficulties in accessing support services have been established by the findings in this report. While they relate, in the main, to the difficulties advice

\footnotetext{
${ }^{50}$ See for example Pascoe Pleasance, Alexy Buck, Nigel Balmer, Aoife O'Grady, Hazel Genn and Marisol Smith, Cause of Action: Civil Law and Social Justice, (2004) London: Legal Services Commission. ${ }^{51}$ Pascoe Pleasance and Nigel J. Balmer, "The Audacity of Justice: Recession, Redundancy, Rights and Legal Aid" (2010) Social Policy and Society 9 (4), p 485.

${ }^{52}$ Footnote 16, para. 5.35.
} 
organisations are experiencing in meeting the demand for their services, there is the 'hidden' problem of users who lack awareness of advice sources. ${ }^{53}$ Individuals who have a range of personal vulnerabilities are most likely to be unaware of how to access support. For many of these users, the traditional models of providing advice - whereby users approach a legal advice point to make an appointment - may not be effective. ${ }^{54}$ There is no obvious or easy solution to this problem, reinforcing the argument that a proportionate dispute resolution process is needed to reduce the number of problems experienced by these users in particular.

88. There are also some innovative examples of providing support outside the traditional advice models. Bringing support to the user to proactively identify their problems and potential solutions is one such innovation, and can also involve co-operation between advice organisations and relevant Departments. Examples of this include the establishment of mental health in-hospital advice clinics by Law Centre (NI) ${ }^{55}$ and CAB's benefit take-up campaign focusing on vulnerable groups within the population. ${ }^{56}$ Raising awareness of rights, including raising awareness of dispute resolution procedures, may also provide a form of support for hard to reach users. The provision of training on employment law by the LRA through workshops and seminars can constitute support of this nature, and these can be conducted in-house at an organisation's request.

89. The provision of legal education for the general public has the potential to reach users who do not participate in other support networks. ${ }^{57}$ Examples of innovations here include providing information on benefit entitlements for parents through information sessions held in schools. Legal education of this nature is usually provided by community advice organisations but there is considerable scope here also for pro-bono work from solicitors and barristers, and for the involvement of law students. ${ }^{58}$ The provision of legal education for users is not a substitute for effective support for users, but it may assist in identifying the need for and means of accessing the necessary support. Raising awareness of legal rights, obligations and dispute resolution processes for those outside the advice sector from whom users may seek advice, such as healthcare professionals and

\footnotetext{
${ }^{53}$ See Pleasance and Balmer, footnote 50, for further discussion on reasons why individuals fail to obtain advice, related to a lack of understanding or capacity by the individual of their position or options, and due to other factors such as shame, insecurity and resignation.

${ }^{54}$ See footnote 21; Alexy Buck, "Reaching further through outreach advice" in A. Buck, P. Pleasance and N.J. Balmer (eds.) Transforming Lives: Law and Social Process (2007) Norwich: TSO.

${ }^{55}$ See for example Law Centre (NI) Annual Report 2010, Social Justice Matters, available at: www.lawcentreni.org/publications/annual-reports/735-annual-report-2010-social-justicematters.html

${ }^{56}$ See for example CAB Annual Report 2010, Changing Times, Changing Services, p17 available at: www.citizensadvice.co.uk/PageFiles/4064/Annual\%20Report\%202010.pdf. See also the provision of advocacy services by ICAS in various out-reach centres: see footnote 31 .

${ }^{57}$ See for example Nigel J. Balmer, Alexy Buck, Ash Patel, Catrina Denvir, Pascoe Pleasence, Knowledge, capability and the experience of rights problems (2010) Plenet: London.

${ }^{58}$ The development of the Legal Support Project run by Law Centre (NI) and the existence of a Northern Ireland Lawyers Pro-Bono Group could provide a means of taking this forward (see: www.barlibrary.com/about-us/ni-lawyers-pro-bono-group/) as could developments in clinical law programmes at the University of Ulster.
} 
politicians, is an additional necessary consideration, as is establishing better connections between advisers and those who could refer individuals for advice.

90. Re-imagining the nature of support networks is also a consideration. Users within this research who utilised online resources responded positively to the idea of online forums as a means of getting information and support. This connects once again to earlier findings that users do not approach the issue of support as a legal issue, but see legal problems as an additional manifestation of existing problems, and will look for support in the same places as they have done for other aspects of the problem. Clearly for online forums to be effective there is a need for some control mechanisms, bringing with it resource implications which would need to be explored. However, online forums could potentially provide an additional means to reach users, and develop user awareness of legal rights and sources of support. They could also provide a further vehicle for co-operation between relevant Departments and support organisations.

\section{Recommendation 11}

Identify and develop innovative models of providing information and support to tribunal users beyond the traditional advice models.

\section{Recommendation 12}

Identify and develop methods of providing public legal education for users and for those outside the advice sector from whom users may seek advice, such as health care professionals and politicians.

\section{Research and oversight}

91. This research has established that users of the three tribunals require some form of support to challenge or respond to a decision under dispute. Where users were able to access support they found this to be helpful, and users who were not able to access support identified gaps in their knowledge and experience that impacted on their ability or their confidence in pursuing a dispute. Some very good examples of support are also evident from this research, but there is no doubt that a gap exists for tribunal users in accessing pre-hearing information and advice. It is hoped that this report develops an understanding of the nature of that deficiency and how it might be addressed, but it must be recognised that the research has only begun to develop that understanding. There remains a considerable research gap in understanding the pre-hearing information and advice needs of tribunal users in Northern Ireland and how best to meet those needs:

\section{Recommendation 13}

Further research should be conducted with a representative sample of tribunal users to understand the experiences of tribunal users in Northern Ireland.

92. While further research can develop our understanding of users' needs, there is also a need to have effective oversight of the work of tribunals in providing support for tribunal users, to ensure that progress is made against the recommendations that have been developed. The final recommendation of this report therefore reiterates 
the recommendation from Redressing Users' Disadvantage that an oversight body be created to champion the cause of tribunal users. While the Coalition government announced its intention to abolish the Administrative Justice and Tribunals Council (AJTC), this report recommends the approach of the Scottish Committee of the AJTC, which clearly concludes on the continuing need for an AJTC-type body for a reformed Scottish tribunal system. ${ }^{59}$ As Northern Ireland develops its programme for tribunal reform, the case for creating an oversight body remains firm as Brian Thompson makes clear in the companion research to this project, examining the potential to restructure Northern Ireland tribunals. ${ }^{60}$ This report therefore adopts the recommendations made by Thompson to create an advisory body for administrative justice, linked with civil and family justice:

\section{Recommendation 14}

There should be an inter-disciplinary advisory body established to contribute to the oversight of tribunals and administrative justice but this body should be connected to other advisory bodies for civil and family justice so as to reflect the system approach which acknowledges the links, overlaps and gaps amongst the components of the legal system and to counteract undue focus on the criminal justice system.

\section{Recommendation 15}

This body, the Northern Ireland Civil and Administrative Justice Advisory Committee (NICAJAC) should be chaired by the Lord Chief Justice and have reporting to it sub-committees for Civil, Family and Administrative Justice. The chair and one member of each sub-committee shall be members of the committee which will meet biannually. The sub-committees could meet quarterly. The membership should include judges and legal practitioners, and in reflecting users' interests at this peak level, advice bodies and academics engaged in research. The Northern Ireland Ombudsman should be an ex officio member of the Administrative Justice sub-committee and possibly of the main committee.

The Access to Justice Review Northern Ireland Report recognises that "at a time of economic stringency, when public services are liable to be pared back, the machinery for addressing disputes between the individual and public agencies is likely to assume increased significance." ${ }^{\prime 1}$ In this context it is hoped that progress can now be made against the recommendations within this report, and those of Redressing Users' Disadvantage, to assist those individuals who may need to access the machinery of public decision making and adjudication.

\footnotetext{
${ }^{59}$ AJTC Scottish Committee, Tribunal Reform in Scotland: A Vision for the Future, 2011, pp41-43.

${ }^{60}$ Brian Thompson, Structural Tribunal Reform in Northern Ireland: Proposals, October 2011, recommendations 9 and 10 .

${ }^{61}$ Footnote 16, para. 5.115.
} 


\section{APPENDIX A}

Redressing Users' Disadvantage: Proposals for Tribunal Reform in Northern Ireland, by Gráinne McKeever and Brian Thompson (2010) Belfast: Law Centre (NI) ISBN 1872299075, 96pp.

\section{Recommendations:}

1. Users must be the focus of the Department of Justice and its policy and executive units in relation to tribunals and administrative justice.

2. Clearly expressed information about challenges to decisions must be made available in a range of languages and formats detailing types of remedies, their possible outcomes, processes, what users can expect and what they must do to pursue a challenge.

3. Tribunal users should be given access to independent, good quality advice, support and representation, and the documentation and processes for claiming such advice and support must not be complex.

4. Tribunal users should have a right to an accessible and affordable appeal on a point of law.

5. The tribunal environment should be user friendly and appropriate to the hearing of a dispute, and users should be consulted on what may be considered to be user friendly tribunal accommodation.

6. In addition to regular customer experience surveys of tribunals and the creation of users' groups, consideration should be given to the commissioning of research into awareness and experience of tribunal appeals and the associated advice, information and support services.

7. Rules of procedure for tribunals should incorporate an overriding obligation to deal with cases fairly and justly and consideration should be given to devising generic rules.

8. Consideration should be given to adopting the overall approach of Proportionate Dispute Resolution which seeks to prevent, reduce and resolve disputes.

9. Policy for, and provision of, information, advice and support including legal representation should be developed across criminal, civil and administrative justice, which includes tribunals.

10. There should be a duty to develop innovative techniques for the resolution of disputes by courts and tribunals. 
11. The guarantee of judicial independence should be extended to all tribunal members in Northern Ireland. The Lord Chief Justice should be responsible for maintaining appropriate arrangements for their welfare, training and guidance and for their deployment in the tribunals of the Northern Ireland Courts and Tribunals Service.

12. Training for tribunal members should be competency based and this should be provided by the Judicial Studies Board of Northern Ireland and by other appropriate providers covering generic judge-craft and jurisdiction specific knowledge and skills. In addition to induction and continuing education and training, this should include support through mentoring, performance management and appraisal.

13. The Lord Chief Justice should be responsible for arrangements for the appraisal of tribunal members.

14. Appointments to all Northern Ireland tribunals should be by the Northern Ireland Judicial Appointments Commission following competitions for which they are responsible.

15. Tribunal members should continue to be deployed in more than one tribunal jurisdiction where they have the relevant expertise and training.

16. Those tribunals for which the Department of Justice is not completely responsible should be transferred to it from their current sponsoring Departments.

17. Consultation should be conducted immediately to determine if it would feasible and useful to:

a. restructure the tribunals into an amalgamated tribunal or a civil and administrative tribunal; and

b. create an appellate division for an amalgamated tribunal or a civil and administrative tribunal and whether such an appellate division should be given a judicial review jurisdiction.

18. A Northern Ireland Administrative Justice and Tribunals Council (NIAJTC) should be established with a remit to keep the administrative justice system of Northern Ireland under review, to consider ways of making the system accessible, fair and efficient, to advise Northern Ireland Ministers and the Lord Chief Justice of Northern Ireland on the development of the system, to refer to those persons proposals for changes in the system and to make proposals for research.

19. The NIAJTC should be appointed by the Northern Ireland Minister for Justice after public competition. The membership should not number fewer than four nor more than six persons, with the Northern Ireland Ombudsman as an ex officio member. In the consultation exercise on the reform proposals, views 
should be sought on whether the UK Parliamentary Ombudsman should be (a) a statutory member or (b) invited to attend as an observer, and how (a) might be done given the constitutional position.

20. The NIAJTC should be able to report on matters within remit causing concern at its own initiative and be asked to report on matters referred to it by Ministers. It should prepare three year strategy plans and annual action plans, consult the Civil Justice Committee, the Social Security Advisory Committee and the Northern Ireland Law Commission, and publish annual reports.

21. Pending the preparation and enactment of legislation on tribunal reform in Northern Ireland, action on the provision of information, advice and support to tribunal users and improving the training of tribunal members can be conducted without legislation, and the Minister of Justice should appoint an Administrative Justice Steering Committee, chaired by a judge, with members drawn from tribunal presidents, civil servants, the advice community, academics and the Northern Ireland Ombudsman and perhaps also the Comptroller and Auditor General. This group should be responsible for conducting consultations on structural changes to tribunals - amalgamation with first instance and appellate divisions. This work should be done within six months. In addition, the Steering Group should pave the way for the work of a NIAJTC by commissioning a study to map the administrative justice system in Northern Ireland and its boundaries with UK-wide bodies as well as conducting work which will promote greater understanding of the administrative justice system, the relationships between the various remedies within the system for putting things right and the relationship between that and getting things right.

22. Legislation should be enacted by 2012:

- to provide that all new tribunals will be the responsibility of the Department of Justice;

- to provide judicial leadership of tribunals by the Lord Chief Justice;

- to extend the guarantee of judicial independence to tribunals;

- to provide procedural rules to include the overriding objective of dealing with a case fairly and justly;

- to establish a NIAJTC; and

- to provide for structural changes to tribunals, if supported in consultation. 


\section{APPENDIX B}

\section{Information and advice sources in Northern Ireland}

Table 1: Social security law information and advice sources

\begin{tabular}{|c|c|}
\hline \multicolumn{2}{|c|}{ NORTHERN IRELAND GOVERNMENT DEPARTMENTS } \\
\hline $\begin{array}{l}\text { Department for Social Development NI } \\
\text { www.dsdni.gov.uk } \\
\text { Contacts are listed A-Z, covering all DSD } \\
\text { offices and services, including all Social } \\
\text { Security Agency offices }\end{array}$ & $\begin{array}{l}\text { - Links on DSD website to the law relating to } \\
\text { social security and child support, and databases of } \\
\text { Social Security Commissioners decisions (NI and } \\
\text { GB) } \\
\text { - Links to The Appeals Service, covering what The } \\
\text { Appeals Service is and what happens at tribunals. } \\
\text { This information is also available as a } \\
\text { publication. } \\
\text { - Links to other Appeals Service publications } \\
\text { inlcuding complaints service and Standards of } \\
\text { practice. } \\
\text { - List of links to other useful organisations, } \\
\text { including advice organisations } \\
\text { - Links to the Social Security Agency }\end{array}$ \\
\hline $\begin{array}{l}\text { Department of Justice NI } \\
\text { www.dojni.gov.uk/index.htm } \\
\text { Block B, Castle Buildings } \\
\text { Stormont Estate, Belfast, BT4 3SG } \\
\text { Telephone: (028) } 90763000 \\
\text { Textphone: (028) } 90527668\end{array}$ & $\begin{array}{l}\text { - Links to NI Courts and Tribunals Service, with } \\
\text { links from here to The Appeals Service }\end{array}$ \\
\hline \multicolumn{2}{|l|}{ STATUTORY BODIES AND AGENCIES } \\
\hline $\begin{array}{l}\text { Social Security Agency } \\
\text { www.dsdni.gov.uk/index/ssa.htm } \\
\text { Offices listed under A-Z of SSA offices } \\
\text { Benefit Enquiry Line: } 0800220674 \\
\text { Minicom: } 0800243787 \text { (free call) }\end{array}$ & $\begin{array}{l}\text { Links to leaflets on: } \\
\text { - } \text { Compensation Recovery leaflets } \\
\text { - } \text { Social Security appeals and complaints leaflets } \\
\text { Social Security disability and caring for someone } \\
\text { - } \frac{\text { leaflets }}{\text { Social Security ill or injured leaflets }} \\
\text { - } \text { Social Security looking for work leaflets } \\
\text { - } \frac{\text { Social Security low income leaflets }}{\text { Social Security pensions and retirement planning }} \\
\text { Links to details of phone services: } \\
\text { - } \text { A to Z of Social Security Agency offices } \\
\text { - } \text { Benefit Enquiry Line } \\
\text { - } \text { Benefit Leaflet Information Service } \\
\text { - } \frac{\text { Crisis Loans Claim Line }}{\text { Pension Service Application Line - for new }} \\
\text { - } \frac{\text { Pension Credit applications }}{\text { Pension Service Enquiry Line (general Pension }} \\
\text { - } \text { Credit enquiries } \\
\text { Pension Service Tele-Claims (State Pensions) }\end{array}$ \\
\hline
\end{tabular}




\begin{tabular}{|c|c|}
\hline $\begin{array}{l}\text { The Appeals Service } \\
\text { www.dsdni.gov.uk/index/taser- } \\
\text { appeals service.htm } \\
\text { Cleaver House, 3 Donegall Square North } \\
\text { Belfast BT1 5GA } \\
\text { Telephone: (028) } 90518518 \\
\text { email:Appeals.Service.Belfast@dsdni.gov.uk } \\
\text { 12-14 Dublin Road } \\
\text { Omagh BT78 1ES } \\
\text { Telephone: (028) 82249595 } \\
\text { email:Appeals.Service.Omagh@dsdni.gov.uk }\end{array}$ & 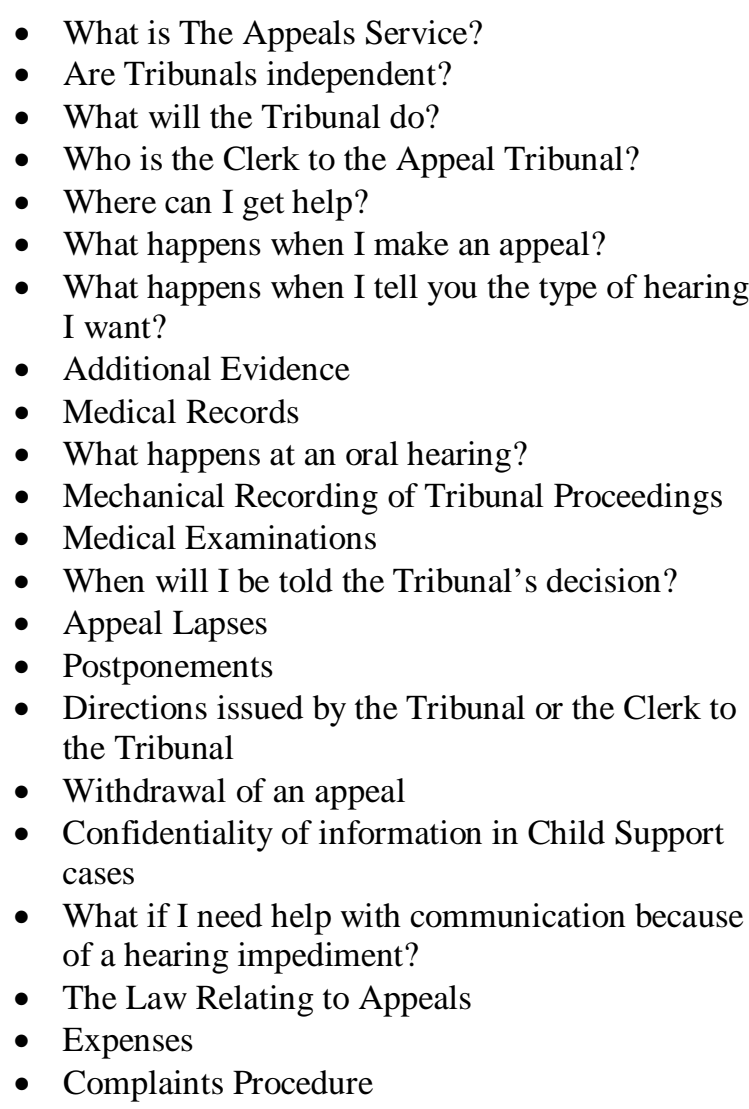 \\
\hline \multicolumn{2}{|l|}{ ADVICE AGENCIES } \\
\hline $\begin{array}{l}\text { CAB www.citizensadvice.co.uk } \\
\text { Various offices and contact details } \\
\text { Central Belfast CAB } \\
\text { Merrion Business Centre, } 58 \text { Howard St } \\
\text { Belfast, BT1 6PJ } \\
\text { Telephone: (028) 9026 1970 } \\
\text { ecentralbelfast@citizensadvice.co.uk }\end{array}$ & $\begin{array}{l}\text { - Advice guide on benefits: } \\
\text { www.adviceguide.org.uk/nireland/ } \\
\text { your_money/benefits_northern_ireland.htm } \\
\text { with Frequently Asked Questions about benefits } \\
\text { - Benefit calculator } \\
\text { - Fact sheets on different benefits }\end{array}$ \\
\hline $\begin{array}{l}\text { Advice NI www.adviceni.net } \\
\text { Main office: } \\
1 \text { Rushfield Avenue, Belfast BT7 3FP } \\
\text { Tel: (028) } 90645919 \\
\text { Fax: (028) } 90492313\end{array}$ & $\begin{array}{l}\text { Umbrella organisation for various independent } \\
\text { advice centres in NI. } \\
\text { - Online Benefit Calculator }\end{array}$ \\
\hline $\begin{array}{l}\text { Law Centre (NI) www.lawcentreni.org } \\
\text { Belfast Office: } \\
\text { 124 Donegall Street, Belfast BT1 2GY } \\
\text { Telephone: (028) } 90244401 \\
\text { Fax: (028) 9023 } 6340 \\
\\
\text { Western Area Office: } \\
9 \text { Clarendon Street, Derry BT48 7EP } \\
\text { Telephone: } 02871262433 \\
\text { Fax: } 02871262343\end{array}$ & $\begin{array}{l}\text { Online information includes: } \\
\text { - Encyclopedia of Rights, covering Benefits, Tax } \\
\text { Credits and Community Care } \\
\text { - Links to, and contact details of, other relevant } \\
\text { organisations }\end{array}$ \\
\hline
\end{tabular}


Table 2: Employment law information and advice sources

\begin{tabular}{|c|c|}
\hline \multicolumn{2}{|c|}{ NORTHERN IRELAND GOVERNMENT DEPARTMENTS } \\
\hline $\begin{array}{l}\text { Department for Employment and Learning } \\
\text { www.delni.gov.uk/er } \\
\text { Adelaide House, 39-49 Adelaide Street } \\
\text { Belfast, BT2 8FD } \\
\text { Telephone: (028) } 90257777 \text { (Monday to } \\
\text { Friday 9am to 5pm) } \\
\text { Fax: (028) 9025 7778 } \\
\text { Email: del@nics.gov.uk? }\end{array}$ & $\begin{array}{l}\text { Employment Rights publications - series of } \\
\text { booklets on variety of employment law issues } \\
\text { - General advice on Employment Rights; Resolving } \\
\text { Disputes at Work; Paid Holiday Entitlement; } \\
\text { Employment Agencies; and Redundancy } \\
\text { Links from DEL website to NI Direct website, with } \\
\text { links to basic employment law information }\end{array}$ \\
\hline $\begin{array}{l}\text { OFMDFM } \\
\text { www.ofmdfmni.gov.uk } \\
\text { Email: ps.ministers@ofmdfmni.gov.uk } \\
\text { Telephone: (028) } 90528400\end{array}$ & $\begin{array}{l}\text { - Employment Equality (Age) - links to relevant } \\
\text { legislation and fact sheets } \\
\text { - } \quad \text { Disability (links to relevant legislation) } \\
\text { - } \text { Fair Employment (brief description of relevant } \\
\text { legal terms and definitions) } \\
\text { - Gender Equality - description of OFMDFM } \\
\text { gender equality strategy } \\
\text { - Sex Discrimination and Equal Pay (covering the } 2 \\
\text { main pieces of legislation, and EU Directives) } \\
\text { - Sexual Orientation (with hyper-links to range of } \\
\text { legislation and 'useful links' to LGBT } \\
\text { organisations) }\end{array}$ \\
\hline \multicolumn{2}{|l|}{ STATUTORY BODIES } \\
\hline $\begin{array}{l}\text { OITFET www.employmenttribunalsni.co.uk } \\
\text { Killymeal House, } 2 \text { Cromac Quay } \\
\text { BELFAST BT7 2JD } \\
\text { Telephone: (028) } 90327666 \\
\text { Fax (028) 9023 } 0184 \\
\text { email: mail@employmenttribunalsni.org }\end{array}$ & $\begin{array}{l}\text { - A linked list of useful organisations } \\
\text { - Links to relevant legislation } \\
\text { - Publications available, including forms, guidance } \\
\text { notes, and tribunal procedures booklet }\end{array}$ \\
\hline $\begin{array}{l}\text { Labour Relations Agency } \\
\text { www.lra.org.uk } \\
\text { 2-8 Gordon Street, Belfast, BT1 2LG } \\
\text { Telephone: (028) } 90321442 \\
\text { Fax:(028) 9033 } 0827 \\
\text { Email: info@lra.org.uk }\end{array}$ & $\begin{array}{l}\text { Employment Q\&A on Annual Leave; Dismissal; } \\
\text { Discipline and Grievance; Bullying and } \\
\text { Harassment; Wages; Contracts of employment; } \\
\text { Redundancy; Family related employment matters; } \\
\text { Maternity; Absence/Sickness; Notice; Recruitment } \\
\text { and selection; and Working Time Regulations } \\
\text { - Employment legislation } \\
\text { - Information on resolving disputes through } \\
\text { conciliation, mediation, arbitration } \\
\text { - Written advice \& guidance on employment law } \\
\text { matters }\end{array}$ \\
\hline $\begin{array}{l}\text { Equality Commission } \\
\text { www.equalityni.org } \\
\text { Equality House, } 7 \text { - } 9 \text { Shaftesbury Square } \\
\text { Belfast BT2 7DP } \\
\text { Telephone : (028) } 90500600 \\
\text { Textphone : (028) } 90500589 \\
\text { Enquiry Line : (028) } 90890890 \\
\text { Fax : (028) } 90248687\end{array}$ & $\begin{array}{l}\text { Information on Equality Law; Sex discrimination; } \\
\text { Equal pay; Fair employment and treatment; Race } \\
\text { relations; Disability discrimination; Sexual } \\
\text { orientation; and Age } \\
\text { - How we can help } \\
\text { - } \quad \text { Complainant assistance } \\
\text { - Time limits for complaints } \\
\text { - Making a complaint } \\
\text { - Taking a discrimination case - a guide }\end{array}$ \\
\hline
\end{tabular}




\begin{tabular}{|c|c|}
\hline Email : information@equalityni.org & - Case decisions \\
\hline $\begin{array}{l}\text { Health and Safety Executive: } \\
\text { www.hseni.gov.uk } \\
\text { Freephone: } 08000320121 \\
\text { Offices in Belfast, Coleraine, Omagh and } \\
\text { Enniskillen } \\
\text { Headquarters: } \\
83 \text { Ladas Drive, Belfast BT6 9FR } \\
\text { Telephone: (028) } 90243249 \\
\text { Fax: (028) 9023 5383 } \\
\text { Email: hseni@detini.gov.uk }\end{array}$ & $\begin{array}{l}\text { - Brief description of workers' rights and } \\
\text { employers' responsibilities, and links and leaflets } \\
\text { to legislation and codes of practice }\end{array}$ \\
\hline \multicolumn{2}{|l|}{ ADVICE AGENCIES } \\
\hline $\begin{array}{l}\text { CAB } \\
\text { Www.citizensadvice.co.uk } \\
\text { Various offices and contact details } \\
\text { Central Belfast CAB } \\
\text { Merrion Business Centre, } 58 \text { Howard St } \\
\text { Belfast BT16PJ } \\
\text { Telephone: (028) } 90261970 \\
\text { ecentralbelfast@citizensadvice.co.uk }\end{array}$ & $\begin{array}{l}\text { - Employment Rights factsheets on maternity rights, } \\
\text { discrimination, working hours, redundancy and } \\
\text { more } \\
\text { - } \text { Frequently asked questions about discrimination } \\
\text { - } \frac{\text { Taking action about race discrimination }}{\text { - }} \\
\text { - } \frac{\text { Daking action about sex discrimination }}{\text { Disability discrimination }} \\
\text { - } \text { Age discrimination at work } \\
\text { Hyper-links to 'Resolving disputes at work in } \\
\text { Northern Ireland' with links to grievance } \\
\text { procedures and applying to a tribunal, with further } \\
\text { contacts listed }\end{array}$ \\
\hline $\begin{array}{l}\text { Law Centre (NI) } \\
\text { www.lawcentreni.org } \\
\text { Belfast Office: } \\
\text { 124 Donegall Street, Belfast BT1 2GY } \\
\text { Telephone: (028) } 90244401 \\
\text { Fax: (028) 9023 } 6340 \\
\text { Western Area Office: } \\
9 \text { Clarendon Street, Derry BT48 7EP } \\
\text { Telephone: (028) } 71262433 \\
\text { Fax: (028) 7126 } 2343\end{array}$ & $\begin{array}{l}\text { Online information includes } \\
\text { - Encyclopedia of Rights, covering rights of } \\
\text { employees and statutory sick pay: } \\
\text { - } \quad \text { Casework bulletins } \\
\text { - Redundancy toolkit } \\
\text { - Links to, and contact details of, other relevant } \\
\text { organisations }\end{array}$ \\
\hline $\begin{array}{l}\text { Advice NI } \\
\text { Www.adviceni.net } \\
\text { Umbrella organisation for various } \\
\text { independent advice centres in NI. } \\
\text { Main office: } \\
\text { Advice NI, } 1 \text { Rushfield Avenue } \\
\text { Belfast BT7 3FP } \\
\text { Telephone: (028) } 90645919 \\
\text { Fax: (028) 9049 } 2313\end{array}$ & $\begin{array}{l}\text { Offices provide independent advice on employment } \\
\text { related issues but no direct links to employment law } \\
\text { issues on the Advice NI website, and no specific } \\
\text { publications on employment rights }\end{array}$ \\
\hline
\end{tabular}




\section{Table 3: Education law information and advice sources}

\begin{tabular}{|c|c|}
\hline \multicolumn{2}{|l|}{ NORTHERN IRELAND GOVERNMENT DEPARTMENTS } \\
\hline $\begin{array}{l}\text { DENI } \\
\text { www.deni.gov.uk } \\
\text { Department for Education } \\
\text { Rathgael House, Balloo Road } \\
\text { Rathgill, Bangor BT19 7PR } \\
\text { Tel: (028) 91279279 } \\
\text { email:mail@deni.gov.uk }\end{array}$ & $\begin{array}{l}\text { - Booklet on SEN - a Guide for Parents, with } \\
\text { some basic information about DARS and appeals } \\
\text { to SENDIST. Available online or in hard copy, } \\
\text { on request. } \\
\text { - Links to ELBs } \\
\text { - Links to the Five Board Advice and Information } \\
\text { Service, at www.education-support.org - the } \\
\text { main vehicle for providing information on SEN } \\
\text { policy and legislation, and SENDIST }\end{array}$ \\
\hline \multicolumn{2}{|l|}{ STATUTORY BODIES AND AGENCIES } \\
\hline Education and Library Boards & $\begin{array}{l}\text { - All (except SEELB) provide links to } \\
\text { www.education-support.org } \\
\text { - Contact details of relevant SEN officers in each } \\
\text { Board }\end{array}$ \\
\hline $\begin{array}{l}\text { Health and Social Care Trusts } \\
\text { www.n-i.nhs.uk/index.php?link=trusts } \\
\text { Five Trusts (Belfast, Northern, Southern, South } \\
\text { Eastern, Western) }\end{array}$ & $\begin{array}{l}\text { Provision of services to assist children with } \\
\text { disabilities in schools }\end{array}$ \\
\hline $\begin{array}{l}\text { SENDIST: } \text { www.courtsni.gov.uk/en- } \\
\text { GB/Tribunals/SpecialEduNeedsnDisability, on } \\
\text { the NICTS website www.courtsni.gov.uk } \\
\text { 3rd Floor, Bedford House, 16-22 Bedford Street } \\
\text { Belfast BT2 7FD } \\
\text { Tel: (028)9072 } 8757 \\
\text { Fax: (028)90313510 } \\
\text { Email: SENDtribunal@courtsni.gov.uk }\end{array}$ & $\begin{array}{l}\text { Information on } \\
\text { - What is the SEND Tribunal; } \\
\text { - } \quad \text { Is then can I appeal? } \\
\text { - If I appeal can I keep talking to the board? } \\
\text { - How is a Tribunal panel made up? } \\
\text { - How do I appeal? } \\
\text { Links to www.education-support.org }\end{array}$ \\
\hline $\begin{array}{l}\text { Equality Commission } \\
\text { www.equalityni.org } \\
\text { Equality House, 7-9 Shaftesbury Square } \\
\text { Belfast BT2 7DP } \\
\text { Telephone : (028) } 90500600 \\
\text { Textphone : (028) } 90500589 \\
\text { Enquiry Line : (028) } 90890890 \\
\text { Fax : (028)90 248687 } \\
\text { Email : information@equalityni.org }\end{array}$ & $\begin{array}{l}\text { - Brief outline of what the main legislation on } \\
\text { special educational needs (SENDO 2005, as } \\
\text { amended) covers. }\end{array}$ \\
\hline $\begin{array}{l}\text { NICCY www.niccy.org } \\
\text { Millennium House, 17-25 Great Victoria Street } \\
\text { Belfast BT2 7BA } \\
\text { Telephone: (028) } 90311616 \\
\text { Minicom: (028) } 90316393 \\
\text { Fax: (028) 9031 } 4545 \\
\text { Email: info@niccy.org }\end{array}$ & $\begin{array}{l}\text { Conducts policy work on children's rights, and has a } \\
\text { legal team to deal with individual cases for children } \\
\text { and young people regarding services they receive } \\
\text { from Schools and other public services. }\end{array}$ \\
\hline
\end{tabular}




\begin{tabular}{|c|c|}
\hline \multicolumn{2}{|l|}{ ADVICE AGENCIES } \\
\hline $\begin{array}{l}\text { CAB www.citizensadvice.co.uk } \\
\text { Various offices and contact details } \\
\text { Central Belfast CAB } \\
\text { Merrion Business Centre, } 58 \text { Howard St } \\
\text { Belfast BT1 6PJ } \\
\text { Telephone: (028) } 90261970 \\
\text { ecentralbelfast@citizensadvice.co.uk }\end{array}$ & $\begin{array}{l}\text { Provides links to different organisations, including } \\
\text { Contact a Family Northern Ireland; Disability } \\
\text { Action (Northern Ireland); SKILL in Northern } \\
\text { Ireland; RNID in Northern Ireland; Children in } \\
\text { Northern Ireland; Parents' Advice Centre (Northern } \\
\text { Ireland); Autism NI }\end{array}$ \\
\hline $\begin{array}{l}\text { Special Educational Needs Advice Centre } \\
\text { (SENAC) www.senac.co.uk } \\
\text { Graham House } \\
\text { Knockbracken Healthcare Park } \\
\text { Saintfield Road, Belfast BT8 8BH } \\
\text { Telephone Advice Line: (028) } 90795779 \\
\text { Fax: (028) 9070 5633 } \\
\text { Email: info@senac.co.uk }\end{array}$ & $\begin{array}{l}\text { Provides an independent advice, information and } \\
\text { advocacy service for parents of children and young } \\
\text { people with special educational needs up to the age } \\
\text { of } 19 \text { across a wide range of learning difficulties. }\end{array}$ \\
\hline $\begin{array}{l}\text { Children's Law Centre (Northern Ireland): } \\
\text { www.childrenslawcentre.org } \\
\text { 3rd Floor, Philip House } \\
\text { 123-137 York Street } \\
\text { Belfast BT15 1AB } \\
\text { Telephone: (028) } 90245704 \\
\text { Freephone Advice Line: } 08088085678 \\
\text { Fax: (028) 9024 5679 } \\
\text { E-mail: info@childrenslawcentre.org }\end{array}$ & $\begin{array}{l}\text { Freephone advice line for SEN queries, and tribunal } \\
\text { representation for strategic cases. Members-only } \\
\text { access to publications. }\end{array}$ \\
\hline
\end{tabular}





\section{Supporting Tribunal Users}

Access to pre-hearing information, advice

and support in Northern Ireland

Law Centre (NI), Belfast Office

124 Donegall Street

Belfast BT1 2GY

Telephone: 02890244401

Faxt 02890236340

Western Area Office

9 Clarendon Street

Derry BT48 7EP

Telephone: 028711262433

Fax: 028711262343

Website

ww.lawcentreni.org

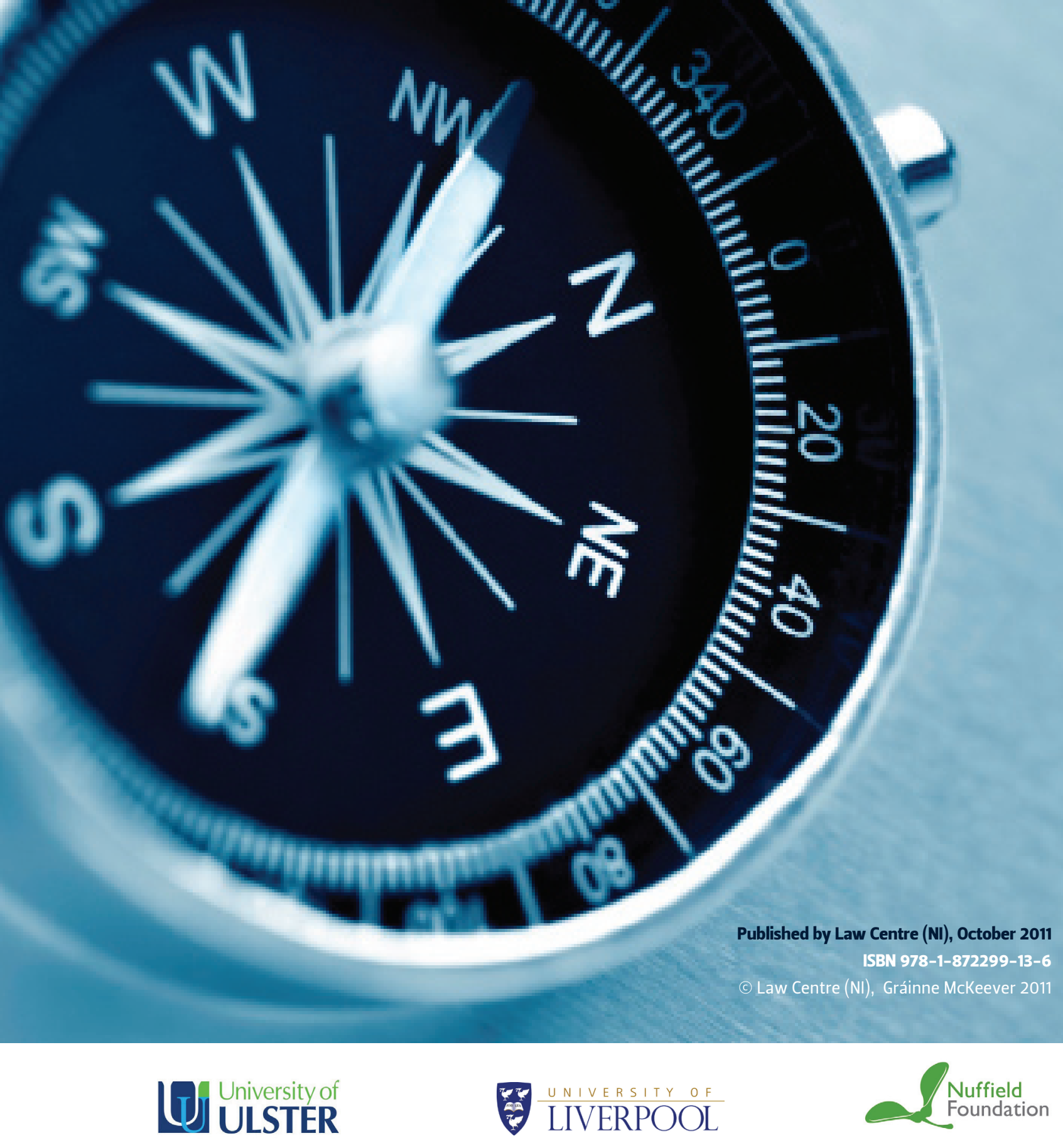

